\title{
Understanding metabolic alterations and heterogeneity in cancer progression through validated immunodetection of key molecular components: a case of carbonic anhydrase IX
}

\author{
Martina Takacova ${ }^{1} \cdot$ Ivana Kajanova $^{1} \cdot$ Maria Kolarcikova $^{1} \cdot J_{a n a}$ Lapinova $^{1} \cdot$ Miriam Zatovicova $^{1}$. \\ Silvia Pastorekova ${ }^{1}$ (D)
}

Received: 25 October 2021 / Accepted: 8 December 2021 / Published online: 26 January 2022

(C) The Author(s) 2022

\begin{abstract}
Cancer metabolic heterogeneity develops in response to both intrinsic factors (mutations leading to activation of oncogenic pathways) and extrinsic factors (physiological and molecular signals from the extracellular milieu). Here we review causes and consequences of metabolic alterations in cancer cells with focus on hypoxia and acidosis, and with particular attention to carbonic anhydrase IX (CA IX). CA IX is a cancer-associated enzyme induced and activated by hypoxia in a broad range of tumor types, where it participates in $\mathrm{pH}$ regulation as well as in molecular mechanisms supporting cancer cells' invasion and metastasis. CA IX catalyzes reversible conversion of carbon dioxide to bicarbonate ion plus proton and cooperates with a spectrum of molecules transporting ions or metabolites across the plasma membrane. Thereby CA IX contributes to extracellular acidosis as well as to buffering intracellular $\mathrm{pH}$, which is essential for cell survival, metabolic performance, and proliferation of cancer cells. Since CA IX expression pattern reflects gradients of oxygen, $\mathrm{pH}$, and other intratumoral factors, we use it as a paradigm to discuss an impact of antibody quality and research material on investigating metabolic reprogramming of tumor tissue. Based on the validation, we propose the most reliable CA IX-specific antibodies and suggest conditions for faithful immunohistochemical analysis of molecules contributing to heterogeneity in cancer progression.
\end{abstract}

Keywords Carbonic anhydrase IX $\cdot$ Metabolism $\cdot$ Heterogeneity $\cdot$ Hypoxia $\cdot$ Acidosis $\cdot$ Antibody validation

\begin{tabular}{|c|c|c|c|}
\hline \multicolumn{2}{|c|}{ Abbreviations } & $\mathrm{HIF}$ & Hypoxia-inducible factor \\
\hline AAT & Amino acid transporter & HRE & Hypoxia-responsive element \\
\hline $\mathrm{AE}$ & Anion exchanger & $\mathrm{IC}$ & Intracytoplasmic \\
\hline CA IX & Carbonic anhydrase IX & IF & Immunofluorescence \\
\hline CCRCC & Clear cell renal cell carcinoma & $\mathrm{IHC}$ & Immunohistochemistry \\
\hline DSF & Disease-free survival & $\mathrm{LDH}$ & Lactate dehydrogenase \\
\hline ECD & Extracellular domain & MCT & Monocarboxylate transporter \\
\hline ELISA & Enzyme-linked immunosorbent assay & $\mathrm{NBC}$ & Sodium bicarbonate cotransporter \\
\hline FACS & Fluorescence-activated cell sorting & NHE & Sodium-proton exchanger \\
\hline FL & Full length & $\mathrm{OS}$ & Overall survival \\
\hline \multirow[t]{3}{*}{ GLUT } & Glucose transporter & OXPHOS & Oxidative phosphorylation \\
\hline & & PDK & Pyruvate dehydrogenase kinase \\
\hline & & PFS & Progression-free survival \\
\hline \multicolumn{2}{|c|}{ Martina Takacova and Ivana Kajanova contributed equally to this } & PG & Proteoglycan \\
\hline \multicolumn{2}{|c|}{ work } & RI & Reproducibility index \\
\hline \multirow{2}{*}{\multicolumn{2}{|c|}{$\begin{array}{l}\text { Silvia Pastorekova } \\
\text { silvia.pastorekova@savba.sk }\end{array}$}} & ROS & Reactive oxygen species \\
\hline & torekova@savba.sk & TCA & Tricarboxylic acid \\
\hline & & $\mathrm{TM}$ & Transmembrane \\
\hline $\begin{array}{l}\text { Institu } \\
\text { Biome }\end{array}$ & $\begin{array}{l}\text { of Virology, Department of Tumor Biology, } \\
\text { al Research Center of the Slovak Academy }\end{array}$ & TME & Tumor microenvironment \\
\hline of Scis & s, Dubravska cesta 9,845 05 Bratislava. & WB & Western blotting \\
\hline
\end{tabular}




\section{Introduction}

During cancer progression, tumor cells are exposed to multiple physiological constraints present in the growing tumor tissue. These constraints dynamically change in spatial and temporal manner, generating selection pressures and adaptive responses leading to expansion of cancer cells that are able to survive and sustain proliferation. Selected cancer cell subpopulations exhibit phenotypic plasticity and invasive/pro-metastatic behavior, and contribute to complex tissue architecture with various physiological gradients. One of key adaptations to fluctuating supplies and demands for survival and proliferation of cancer cells is their metabolic reprogramming.

\section{Causes and consequences of metabolic alterations and heterogeneity}

\subsection{Oncogenic activation}

Initial tumor growth is associated with mutations that trigger deregulated oncogenic signaling. Activated oncoproteins and/or inactivated tumor suppressor proteins promote abnormal cell proliferation not only by activating positive regulators and counteracting negative regulators of the cell cycle, but also by redirecting cellular metabolism from oxidative phosphorylation to glycolysis [1-3]. They do so through signal transduction pathways leading to enhanced transcription, translation, and/or catalytic activation of the glycolytic enzymes (including glucose transporter GLUT, lactate dehydrogenase LDH, pyruvate dehydrogenase kinase PDK, and monocarboxylate transporter MCT) as explained in more detail elsewhere. Classical examples of this phenomenon include activated MYC and RAS and inactivated p53, von Hippel-Lindau (VHL), and phosphatase and tensin homolog (PTEN), but also many other regulatory molecules $[4,5]$. In addition, activating mutations can occur directly in the components of the metabolic pathways, such as isocitrate dehydrogenase (IDH), fumarate hydratase (FH), and/or succinate dehydrogenase (SDH) [6-8]. Albeit glycolysis is not as efficient as respiration in energy production, it allows for synthesis of cellular biomass that is particularly important for uncontrolled proliferation of cancer cells $[1,2]$. Yet, most cancer cells retain functional mitochondria that are essential for lipid synthesis and protein acetylation [6].

\subsection{Stresses in tumor microenvironment}

Proliferative advantage of cancer cells enables in situ expansion of tumor lesion until the demands for nutrients and oxygen exceed their supply from the nearest functional blood vessel [9-11]. Long-lasting lack of oxygen (i.e., anoxia) is incompatible with the survival of cells and generates necrotic regions that are histological surrogates of poor cancer prognosis. Lowered oxygenation (i.e., hypoxia) reinforces the shift of cancer cells to glycolytic metabolism and induces additional phenotypic changes, such as angiogenesis generating aberrant tumor vasculature, cell-cell deadhesion linked with migration-invasion, and genomic instability facilitating accumulation of mutations [12]. Mechanisms behind these phenotypic changes include both transcriptional and translational reprogramming governed principally by the hypoxia-inducible transcription factors (HIFs) and by the unfolded protein response (UPR)-driven pathways, as reviewed in [13-16].

Importantly, these adaptations are not uniform. They vary depending on many circumstances including cancer type/ origin, position of cells in the diffusion gradients, and time of their exposure to the hypoxic stress $[11,17]$. Thus, metabolic preferences of the peri-necrotic cancer cells chronically suffering from severe hypoxia considerably differ from the preferences of the moderately hypoxic cells as well as from the oxygenated cells located proximally to the vasculature [18].

In a simplified interpretation, cells in the region of severe hypoxia are highly dependent on glycolysis, while the moderately hypoxic cells can utilize tricarboxylic acid (TCA) cycle and oxidative phosphorylation system (OXPHOS) by consuming lactate exported from the highly glycolytic cells, a phenomenon known as metabolic symbiosis [19, 20]. Normoxic cells exploit glycolysis in the presence of oxygen (socalled Warburg effect) along with TCA/OXPHOS, driven by various fuels available in the tumor microenvironment (TME), including amino acids and lipids $[11,17]$.

Oncogenic metabolism produces an excess of acidic metabolic products, such as lactate, protons, and carbon dioxide. Although these metabolites are primarily generated intracellularly, machinery protecting cancer cells from an intracellular acidosis extrudes them to the pericellular space either by the active export mechanisms or by altering/ reversing their gradients across the plasma membrane [21]. Consequently, these acidic products accumulate in TME (especially when distant from the blood flow) and generate an extracellular acidosis, which has a significant impact on metabolic performance as well as on additional phenotypic characteristics of tumor cells contributing to their pro-metastatic behavior and to cancer progression [18, 22]. Acidosis was shown to directly affect protonation states of important regulatory proteins with $\mathrm{pH}$-sensitive amino acids, as exemplified by p53, sodium-proton exchanger 1 (NHE1), epidermal growth factor receptor (EGFR), B-catenin, etc., thereby causing structural changes that results in their altered functions [23]. Moreover, intracellular acidosis 
leads to increased accumulation of reactive oxygen species (ROS) and enhanced ferroptosis, a non-apoptotic form of iron-dependent cell death [24, 25]. Acidic $\mathrm{pH}$ is also linked with immune cells' anergy and resistance to anticancer drugs [26].

Metabolic heterogeneity is also developing along the cancer progression stages. Invasive and circulating cancer cells depend on the acquisition of an anchorage-independence to avoid anoikis and gain metabolic phenotype overcoming excessive ROS production and bioenergetic crisis caused by the loss of attachment signals. These non-adherent cells require high amounts of ATP for survival (and not the biomass for proliferation), thus relying more on mitochondrial metabolism during their detachment, invasion, and flow within the blood stream or in lymphatics [27-29].

\subsection{Tumor-stroma cross-talk}

Diversity of responses to physiological stresses in TME by cancer cell subpopulations is not the only determinants of the metabolic heterogeneity in tumors. This phenomenon gains complexity through the cross-talk of cancer cells with the cells in stroma. Stroma is a connective component of the tumor tissue showing highly variable extent and composition depending on the organ of residence, tumor type, and cancer stage. Different stromal cells communicate with cancer cells via multiple signaling entities including growth factors, exosomes, and micro-/nanotubular structures, but also via metabolites [17, 30, 31]. Cancer and stromal cells can live in a metabolic symbiosis not only by releasing/consuming lactate, but also by venting of cancer cells-produced $\mathrm{CO}_{2}$ via gap junctions of stromal cells and potentially through additional mechanisms that still remain to be elucidated $[32,33]$.

\subsection{Links between pH control and metabolism}

Successful adaptation of tumor cells to oncogenic metabolism and/or hypoxia strongly depends on activation of the $\mathrm{pH}$ control machinery $[18,34]$. Its prime role is to maintain a slightly alkaline intracellular $\mathrm{pH}(\mathrm{pHi} \sim 7.2$ to 7.7$)$ that is required for the effective biosynthesis, ATP production, and signaling [35]. Major components of this $\mathrm{pH}$ control machinery can be induced by hypoxia and/or are $\mathrm{pH}$-sensitive molecules, including sodium-proton exchangers (e.g., NHE1), anion exchangers (e.g., AE2), sodium-bicarbonate transporters (e.g., NBCe1), monocarboxylate transporters (MCT1 and MCT4), and related molecules. Moreover, MCTs can also affect the glycolytic flux by mediating co-extrusion of lactate and protons and therefore represent one of the intersecting points of metabolism and $\mathrm{pH}$ control [20, 22, 36].

Besides extrusion of lactate and protons, $\mathrm{pHi}$ control also involves removal of the intracellular $\mathrm{CO}_{2}$ by diffusion to extracellular space as well as the import of bicarbonate ions generated by the hydration of pericellular $\mathrm{CO}_{2}$ to cytoplasm, leaving protons from the same reaction outside the cells. These processes lead to extracellular acidosis that often persists in tumor microenvironment because the acidic metabolic products cannot be effectively removed by the aberrant tumor vasculature. Extracellular acidosis can activate proteolytic enzymes that degrade extracellular matrix and facilitate invasion and metastasis. Moreover, cancer cells with activated $\mathrm{pH}$-regulating machinery can resist toxic effects of extracellular acidosis generated by oncogenic metabolism and even benefit from an acidosis-supported acquisition of aggressive tumor phenotypes. Thus, cancer cells gain selective advantage against surrounding normal cells that cannot adapt [37].

Acidosis strongly influences tumor metabolic preferences, reducing glycolysis while promoting mitochondrial activity. It supports progression-related processes such as angiogenesis, invasion, and metastasis and is linked to cellular phenomena including aneuploidy and mutation rate, autophagy and survival, cell migration, and release of exosomes [18]. Moreover, acidosis is enriched at tumor-stroma interfaces (in addition to regions of chronic hypoxia) and cells within the acidic front are invasive and proliferative [33, 38]. From the clinical point of view, intratumoral acidosis is associated with resistance to chemo-, radio-, and immuno-therapies.

\section{Carbonic anhydrase IX and its role in tumor metabolism}

\subsection{CA IX essentials}

Carbonic anhydrase IX (CA IX) has been initially cloned as a cancer-associated transmembrane enzyme with an active site facing the extracellular space and catalyzing the reversible conversion of carbon dioxide to bicarbonate ion and proton $[39,40]$. CA IX shows very high catalytic activity, comparable to the CA II isoform that belongs to the most active enzymes in general. Interestingly, CA IX activity culminates at acidic $\mathrm{pH}$ around 6.5, typical for tumor microenvironment $[41,42]$. Moreover, CA IX is strongly responsive to hypoxia both at the level of expression by the HIF-mediated transcriptional activation [43], and at the level of catalytic activity by the protein kinase A (PKA)-mediated phosphorylation [44]. In addition, available experimental data show that the expression of CA IX can be induced under normoxic conditions in connection with oncogenic activation of the RAS, SRC, or RET pathway, and upon treatment with glucose, lactate, and glutamine (particularly in combination with serum growth factors) that are important substrates of tumor metabolism [45-49].

CA IX is an important constituent of $\mathrm{pH}$ regulation in tumor cells via contribution to intracellular neutralization/ 
alkalization and extracellular acidification [50-52]. Indeed, CA IX cooperates with a number of genuine $\mathrm{pH}$ regulators mentioned above, including $\mathrm{NBCe} 1$ and $\mathrm{NBCn} 1, \mathrm{MCT} 1$ and MCT4, NHE1, AE2, and NCX1 (Fig. 1) [53-59]. These cooperative activities are mainly dependent on the enzyme active site in the CA domain localized in the central part of the CA IX ectodomain near its transmembrane region, as described in [53-55] and depicted below. However, the $\mathrm{N}$-terminal part (so-called PG region) protruding to the extracellular space participates in the non-catalytic $\mathrm{pH}$ regulation, as an antenna enhancing export of protons coupled with export of lactate ions via MCTs [56-58]. In fact, CA IX acts as an extracellular $\mathrm{pH}$-stat, maintaining an acidic tumor extracellular $\mathrm{pH}$ that is tolerated by cancer cells and supports their pro-metastatic behavior [52]. CA IX-mediated extracellular acidosis is also associated with decreased immune activity in the tumors of patients with a broad spectrum of solid malignancies [60]. At the same time, CA IX stabilizes intracellular $\mathrm{pH}$ that is conducive to survival and proliferation [6, 51]. Recently, Chafe et al. have demonstrated that the role of CA IX in maintaining an alkaline intracellular $\mathrm{pH}$ is critical for suppression of ferroptosis [25].

The effects of CA IX on tumor phenotype can be blunted either by the silencing/suppression of the CA IX expression, or by the small molecule inhibitors of the CA IX catalytic activity, or by the CA IX-specific antibodies as documented in a number of published studies and reviews [61-68]. Moreover, the knowledge obtained in pre-clinical studies of CA IX inhibitors and/or antibodies has opened the window for novel anticancer strategies, some of which have been translated into the clinical trials (reviewed in [69] and listed in https://clinicaltrials.gov].

\subsection{CA IX and metabolic reprogramming}

Since hypoxia and acidosis are intimately coupled with expression and activities of enzymes involved in oncogenic metabolism, it is not surprising that CA IX can play a role in metabolic pathways, echoing intratumoral oxygen and $\mathrm{pH}$ gradients in metabolic heterogeneity of tumor tissue. CA IX expression and/or activity appears to be required for accelerated lactate efflux via MCTs [57, 58], for full expression and activity of PDK1, a gate-keeping enzyme to the TCA cycle in mitochondria [70,71], for full expression and activity of a key glycolytic enzyme LDHA [72], and ultimately for maximizing glycolytic flux and facilitating cell proliferation in hypoxic/acidic TME [73]. This conclusion is in line with the fact that glycolysis both generates and senses $\mathrm{pH}$ changes caused by the formation and accumulation of acidic metabolites [74, 75].
Fig. 1 Schematic view of the CA IX position in molecular pathways driving metabolic reprogramming of cancer cells. Oncogenic activation and hypoxia drive metabolic reprogramming in part via HIF-mediated induction and/or activation of certain glycolytic enzymes (LDHA) and transporters of glucose (GLUT), lactate (MCT), and amino acids (AAT). This allows cancer cells to generate energy and biomass for survival and proliferation. At the same time, HIF induces key components of $\mathrm{pH}$ regulating machinery, including ion transporters (NBC and NCX) as well as carbonic anhydrase IX (CA IX), in order to protect cancer cells from intracellular acidosis generated by the oncogenic metabolism. CA IX cooperates with these molecules via its extracellular domains either in a catalytic or in a non-catalytic manner thereby regulating $\mathrm{pH}$ and supporting metabolic adaptations of cancer cells

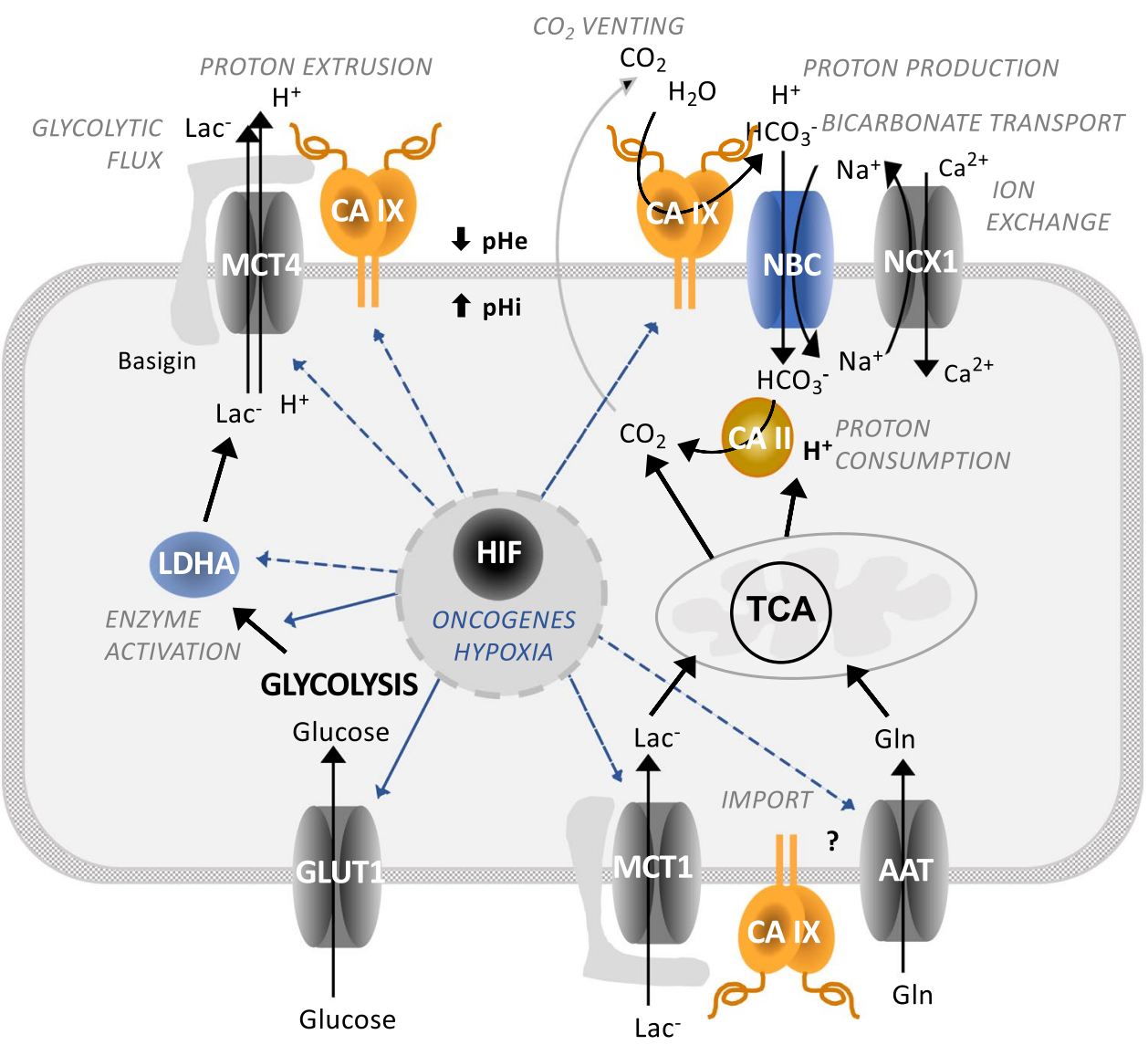


CA IX also plays a role in molecular mechanisms mediating cell adhesion-migration-invasion [76, 77]. On one hand, CA IX can affect the assembly and maturation of focal adhesion contacts during cell attachment and spreading on solid support $[78,79]$, and on the other one, it can destabilize E cadherin-mediated intercellular contacts [80] and facilitate migration/invasion. CA IX re-localizes to cellular leading-edge structures, namely filopodia during migration and invadopodia during invasion, where it contributes to $\mathrm{pH}$ regulation at both sides of the plasma membrane [54, 81]. It operates via coordinated regulation of an interactome composed of bicarbonate transporters and amino acid transporters as well as cortactin, integrins, and metalloproteinases [81-83]. This also implies possible involvement of CA IX in metabolic processes that supply energy both to (1) formation and growth of these highly dynamic subcellular structures potentially via podosome-confined glycolysis, as suggested by Stock and Schwab [84], and (2) movement and protrusion of individual cells or cell clusters via enhanced respiration, mitochondrial biogenesis, and reduced lipogenesis $[85,86]$.

\subsection{CA IX as a surrogate marker of hypoxia, acidosis, and glycolytic metabolism}

CA IX is mostly viewed as a biomarker of hypoxia and/ or acidosis. It is expressed in many tumor types and shows highly heterogeneous expression pattern, as reviewed in [68]. It is usually localized in broader peri-necrotic zones involving both highly and moderately hypoxic cells that are viable and possess a strong metastatic potential. Because of the responsiveness to both severe and moderate hypoxia, CA IX distribution only partly overlaps with that of HIF- $1 \alpha$ and of other hypoxia-regulated proteins induced at different hypoxic thresholds [43, 87, 88]. Occasionally, CA IX distribution is diffused, presumably as a sign of oncogene activation or inactivating mutation of tumor suppressor. CA IX can be also found in HIF- $1 \alpha$ negative areas possibly because reoxygenation leads to instantaneous degradation of the HIF- $1 \alpha$ but not of the highly stable CA IX. In accord with the CA IX role in $\mathrm{pH}$ regulation, its expression is increased at the interface between tumor and stroma, in the acidic front containing invasive and proliferative cells that rely on glycolysis $[9,38]$.

In light of the data connecting CA IX to glycolytic metabolism, CA IX can be viewed as a surrogate indicator of glycolytic metabolic phenotype. Indeed, data from the literature show that in patients' specimens of tumors derived from diverse tissue types, CA IX is often correlated, co-expressed, and/or spatially overlapped with the traditional biomarkers of the glycolytic metabolism (GLUT1, MCTs, LDH) and glucose consumption rate $\left({ }^{18} \mathrm{FDG}\right)$. For example, significant overall correlation and co-localization of CA IX with GLUT1, MCT4, and
MCT1 was demonstrated by immunohistochemistry (IHC) in advanced head and neck carcinomas [89]. Considerable spatial overlap between CA IX and GLUT1 was found in areas of diffusion-limited hypoxia in glioblastomas and astrocytomas [90]. CA IX correlation with GLUT1 was also found in papillary renal cell carcinomas [91], in bladder cancer [92], and in cervical carcinomas [93]. In addition, higher expression of CA IX was linked with the stronger ${ }^{18} \mathrm{FDG}$ uptake in non-small cell lung cancer [94]. CA IX expression was also correlated with LDH5 expression in gastrointestinal adenocarcinomas [95]. Interestingly, analysis of transcriptional profiles of different tumor types fully supports these links (Fig. 2). Altogether, these data reinforce the existence of in vivo link between CA IX and glycolysis.

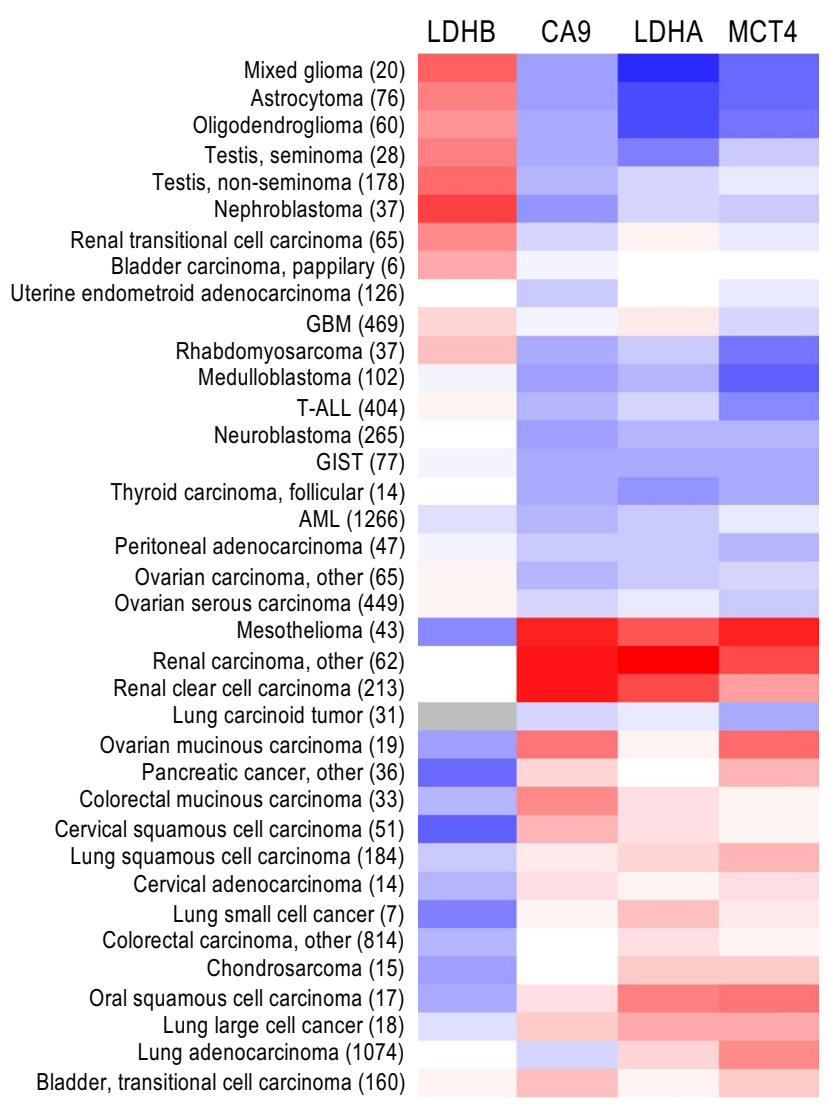

Fig. 2 A heatmap visualizing differential expression of genes coding for the CA IX (CA9) and for the glycolytic enzymes LDHA (supporting glycolysis), LDHB (supporting TCA cycle), and MCT4 (extruding lactate ions and protons) in various tumor samples (the number of samples is indicated in brackets). The color scale ranges from blue (lowest mean expression) through white (average mean expression) to red (highest mean expression). Data were analyzed and extracted through IST (in silico transcriptomics) online (MediSapiens; https:// medisapiens.com/), the largest fully integrated and annotated human gene expression data source 


\section{Challenges for characterizing metabolic heterogeneity in tumor tissues}

Current research of cancer metabolism and metabolic heterogeneity in cancer progression focuses primarily on technologically advanced methods of metabolomics, as reviewed by [96]. However, identification of underlying molecular mechanisms still depends on approaches of molecular/cell biology and cancer physiology. Due to a complex nature of this topic, it is extremely important to employ validated research tools and correct methodical approaches as well as appropriate research material.

The need for antibody validation is particularly evident for molecules that are functionally involved in metabolic pathways, irrespective of whether they are detected in cellular extracts, cultured cells, or in tumor tissues [97]. Once the antibody does not fulfill strict specificity and quality requirements, it can provide false data leading to inaccurate interpretation of results. This can eventually obscure the recognition of a real biological role and/or clinical value of the studied molecule. In addition, such situation can result in impairment of data reproducibility and failure of therapeutic targeting strategies, as witnessed in nowadays' science and clinical R\&D. There are also additional challenges including inappropriate tissue material and data presentation that have to be addressed in order to improve the way towards unraveling tumor heterogeneity.

\subsection{Quality of antibodies}

Looking at the investigations of CA IX as a molecule that contributes to tumor heterogeneity and metabolic reprogramming through response to hypoxia and acidosis, it is evident that researchers use diverse antibodies from various sources, often without proper characterization, just relying on the recommendations in datasheet. To date, more than 1,310 (from 45 providers) and 959 anti-CA IX antibodies are listed in Antibodypedia [98] and CiteAb [99], respectively. Many of these antibodies are routinely used in basic research for detection and quantification of CA IX, as well as for determination of its distribution and interactions within cells. A subgroup of antibodies is also used in clinical studies to reveal the CA IX expression in tissues and its prognostic, diagnostic, and therapeutic potential. However, not all of these antibodies can comply with high standards of performance and reliability.

To clarify this situation, eight commercially available antibodies that are most frequently cited in the numerous clinical studies of CA IX were subjected to a comprehensive validation in our laboratory. Overall reactivity of the antibodies was compared with the providers' recommendations in the datasheets. Table 1 summarizes an overview of the antibody validation results obtained in five applications, namely WB, ELISA, FACS, IF/ICC, and IHC (see the original validation data in the Supplementary information). Antibody binding regions on the CA IX molecule are depicted in Fig. 3. The antibodies were selected predominantly on the basis of meta-analysis performed by van Kuijk and colleagues [100]. There, the data from 147 clinical studies encompassing more than 24,000 cancer patients were evaluated with respect to CA IX expression assessed by IHC in relationship to several endpoints, including overall survival (OS), disease-free survival (DFS), and progression-free survival (PFS). Meta-analysis confirmed the correlation of high CA IX expression to disease progression, locoregional failure, and development of metastasis, independently of tumor type or site. Since most of the included clinical studies

Table 1 Characteristics of antibodies demonstrated by validation compared to recommendations of providers

\begin{tabular}{|c|c|c|c|c|c|c|c|c|c|c|}
\hline & \multicolumn{2}{|c|}{ WB } & \multicolumn{2}{|c|}{ ELISA } & \multicolumn{2}{|c|}{ FACS } & \multicolumn{2}{|c|}{ IF/ICC } & \multicolumn{2}{|c|}{ IHC } \\
\hline & $\mathbf{R}$ & $\mathbf{V}$ & $\mathbf{R}$ & V & $\mathbf{R}$ & $\mathbf{V}$ & $\mathbf{R}$ & $\mathbf{V}$ & $\mathbf{R}$ & $\mathbf{V}$ \\
\hline M75 (m) & $\mathrm{Y}$ & $\mathbf{Y}$ & $\mathrm{Y}$ & $\mathbf{Y}$ & $\mathrm{Y}$ & $\mathbf{Y}$ & $\mathrm{Y}$ & $\mathbf{Y}$ & $\mathrm{Y}$ & $\mathbf{Y}$ \\
\hline ab15086 (r) & $\mathrm{Y}$ & $\mathbf{Y}$ & & $\mathbf{Y}$ & Y & $\mathbf{N}$ & & $\mathbf{Y}$ & $\mathrm{Y}$ & $\mathrm{Y}^{\mathrm{b}}$ \\
\hline $\operatorname{D10C10}(r)$ & $\mathrm{Y}$ & $\mathbf{Y}$ & & $\mathrm{N}$ & & $\mathrm{N}$ & & $\mathbf{Y}^{\mathrm{a}}$ & Y & $\mathrm{Y}^{\mathrm{b}}$ \\
\hline GT12 (m) & Y & $\mathbf{Y}$ & & $\mathrm{N}$ & Y & $\mathbf{N}$ & Y & $\mathbf{N}$ & Y & $\mathbf{N}$ \\
\hline $2 \mathbf{D 3}(\mathrm{m})^{\mathrm{d}}$ & $\mathrm{Y}$ & $\mathbf{N}$ & & $\mathrm{N}$ & $\mathrm{Y}$ & $\mathbf{N}$ & & $\mathrm{N}$ & $\mathrm{Y}$ & $\mathbf{N}$ \\
\hline NB100-417 (r) & $\mathrm{Y}$ & $\mathbf{Y}$ & $\mathrm{Y}$ & $\mathbf{N}$ & $\mathrm{Y}$ & $\mathbf{N}$ & $\mathrm{Y}$ & $\mathbf{Y}$ & $\mathrm{Y}$ & $\mathrm{Y}^{\mathrm{b}}$ \\
\hline AF2188 (g) & $\mathrm{Y}$ & $\mathbf{Y}$ & & $\mathrm{N}$ & $\mathrm{Y}$ & $\mathbf{Y}$ & $\mathrm{Y}$ & $\mathbf{Y}$ & $\mathrm{Y}$ & $\mathbf{Y}^{\mathrm{c}}$ \\
\hline H-11 (m) & $\mathrm{Y}$ & $\mathbf{Y}$ & $\mathrm{Y}$ & $\mathbf{Y}$ & & $\mathbf{Y}$ & $\mathrm{Y}$ & $\mathbf{Y}$ & $\mathrm{Y}$ & $\mathbf{Y}^{\mathrm{c}}$ \\
\hline SAB1300310 (r) & $\mathrm{Y}$ & $\mathbf{Y}$ & $\mathrm{Y}$ & $\mathbf{N}$ & & $\mathbf{Y}$ & & $\mathbf{Y}^{\mathrm{a}}$ & & $\mathbf{Y}^{\mathrm{d}}$ \\
\hline
\end{tabular}

${ }^{\mathrm{a}}$ Only in cells with high ectopic expression

${ }^{\mathrm{b}}$ Only after demasking

${ }^{\mathrm{c}}$ High background

${ }^{\mathrm{d}}$ Clone with the same characteristics is available also as NBP1-51691 and ab107257

${ }^{\mathrm{d}}$ Faint staining signal

$R$, recommended by the provider; $V$, validated in our laboratory; $Y$, yes; $N$, no; $m$, mouse; $r$, rabbit; $g$, goat; red color signifies a disagreement with the provider's recommendation 


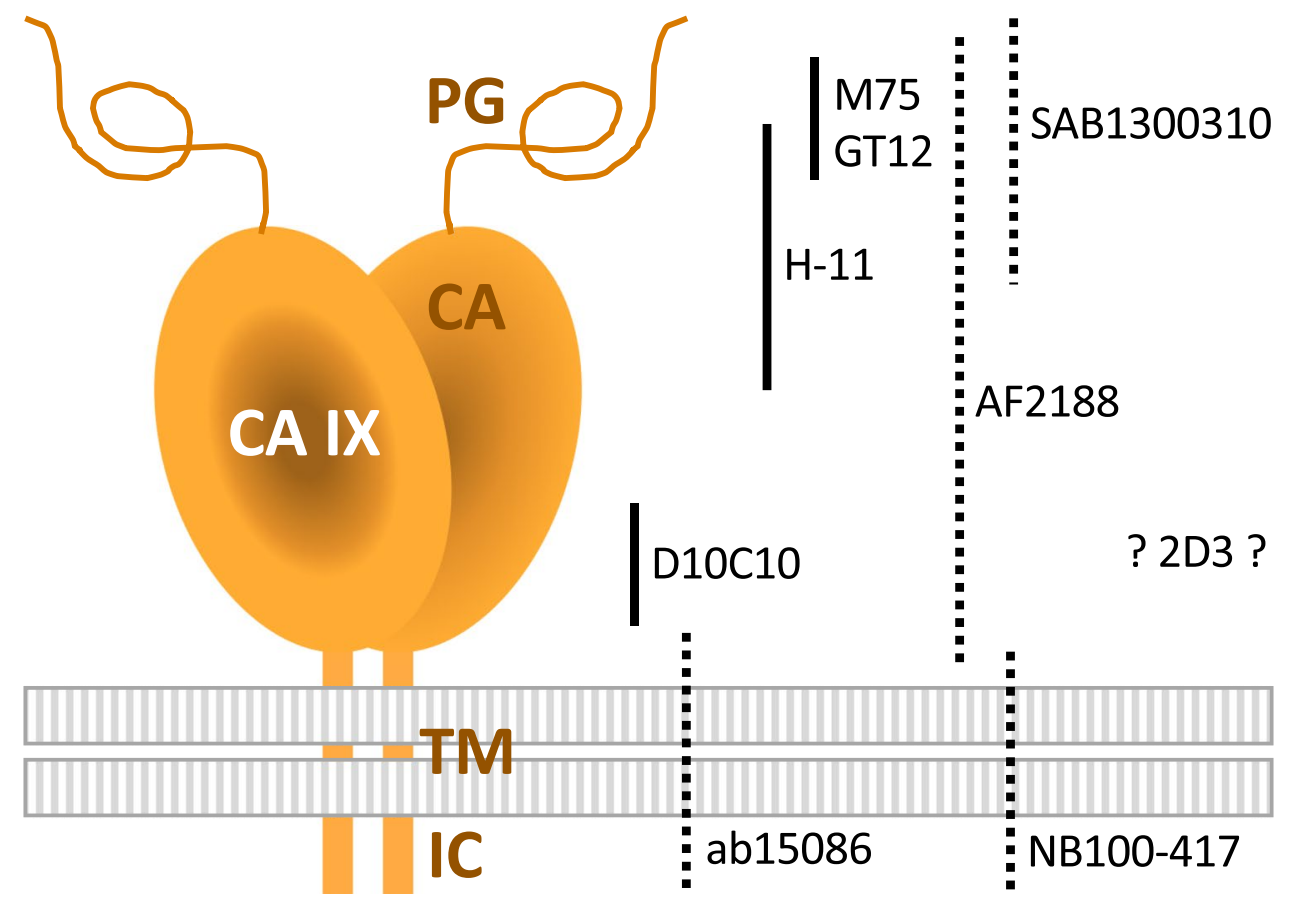

Fig. 3 Schematic illustration of binding sites of M75 and eight validated antibodies. The positions of antibody binding regions are shown on the schematic model of the CA IX protein comprising a proteoglycan-like (PG) region, carbonic anhydrase (CA) domain, transmembrane (TM) anchor, and intracytoplasmic (IC) tail. Antibody arrangement reflects the information available in the datasheets.

(46\%) employed M75 monoclonal antibody, it was used as a reference antibody. Moreover, its CA IX specificity and excellent performance was proven in many other research papers from a number of laboratories. Representative IHC staining with M75 antibody is shown in Fig. 4.

Because IHC is (except metabolomics) a key approach in determining tissue expression of regulators/executors of metabolic reprogramming in tumors and in elucidating their clinical value as potential biomarkers and therapy targets, our validation was focused primarily on this application. Specificity of anti-CA IX antibodies in IHC was examined using serial tissue sections of the clear cell renal cell carcinoma (CCRCC) with proven high expression of CA IX compared to the CA IX-negative normal kidney tissue (Supplementary information). In addition to the M75 reference, additional 3 commercial antibodies were found more or less suitable for IHC, considering specific methodical adjustments, such as requirement for antigen retrieval (citrate or EDTA) as well as duration and temperature of staining ( $1 \mathrm{~h}$ at $\mathrm{RT}$ versus $\mathrm{O} / \mathrm{N}$ at $4{ }^{\circ} \mathrm{C}$ ). Assessment of these methodical details for each particular antibody and their precise description in related publication is extremely important for the reliability and reproducibility of data.

In brief, the validation performed in our laboratory revealed that monoclonal D10C10 and polyclonal antibodies
Monoclonal and polyclonal type of antibody is depicted using full and dashed line, respectively. No information regarding the immunogen used for the generation of 2D3 monoclonal antibody is available in its datasheet. According to "Ten basic rules of antibody validation" [101], all selected antibodies are correctly described by providers and, with exception of 2D3, have a defined immunogen

ab15086 and NB100-417 are reliable alternatives to monoclonal antibody M75, while the antibodies H-11 and AF2188 suffer from non-specific reactivity and high background that may potentially lead to false positivity. The antibodies GT12 and 2D3 are not suitable for the detection of CA IX by IHC.

\subsection{Identification of antibodies and data presentation}

Almost $30 \%$ of the IHC studies involved in the meta-analysis by van Kuijk et al. (2016) [100] contain insufficient description of the used anti-CA IX antibody, missing its unambiguous identification and just mentioning the provider (if at all). In some cases, authors declare an incorrect source of the antibody (see Table 2). Since some providers offer a number of different antibodies to CA IX, this introduces a lot of confusion and questions the data interpretation as well as their reproducibility. However, this drawback is not limited to CA IX-it is a generally occurring and persisting problem in the entire biomedical research, since the antibody cannot be recognized in more than a half of all respective publications (as reviewed by [101]).

Moreover, about $14 \%$ of papers included in the metaanalysis [100]do not display even the representative images of the IHC stained tissues (neither in the articles themselves, 

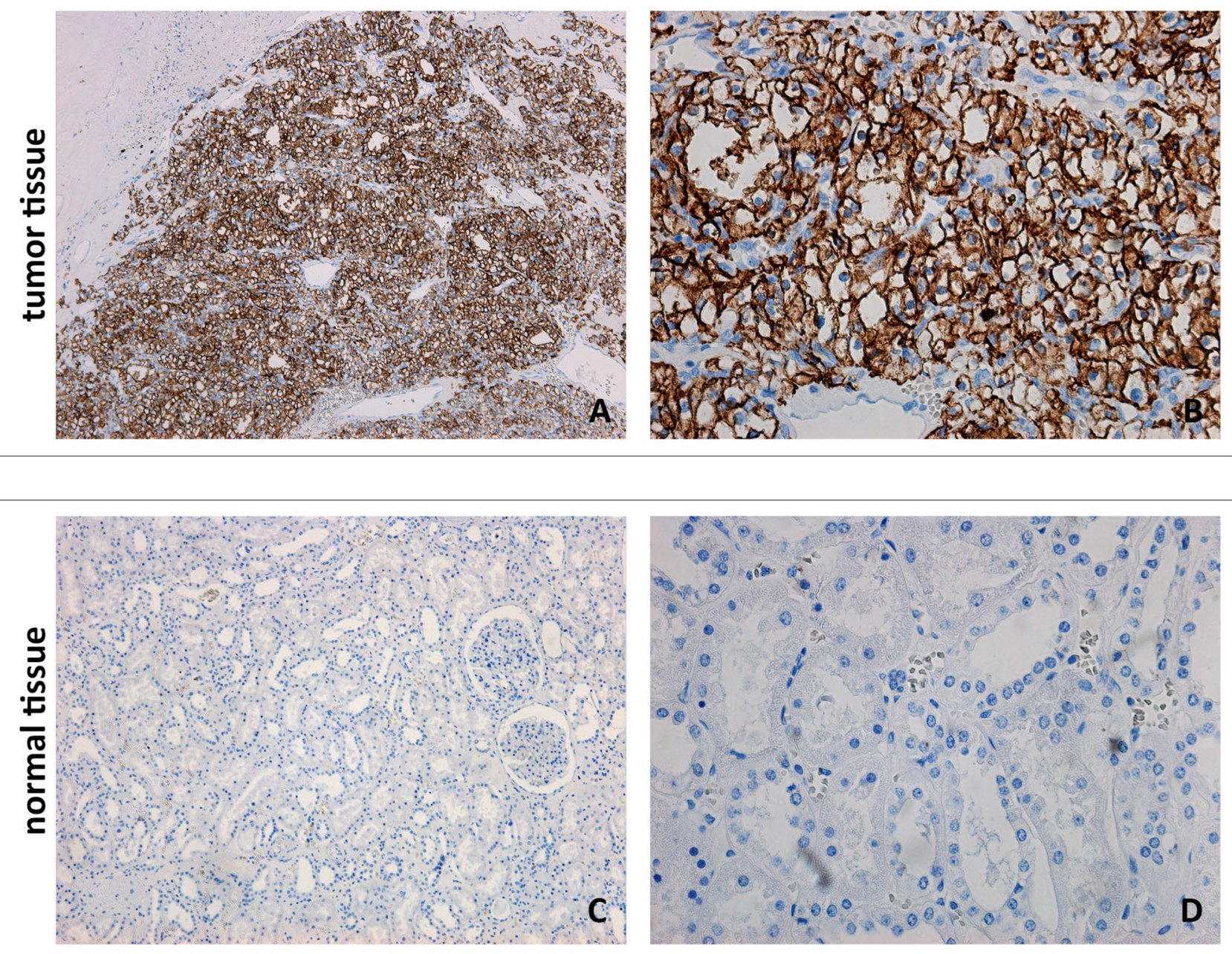

Fig. 4 Representative images from tumor (CCRCC) and normal kidney tissue stained using M75 reference antibody. Tissue sections were directly incubated with M75 monoclonal antibody for $1 \mathrm{~h}$ at RT. Following the incubation with anti-mouse secondary antibody, positive

nor in their Supplementary data), thus precluding a visual inspection of the staining intensity and pattern.

\subsection{Tissue specimens}

Deeper analysis of all CA IX-dedicated IHC studies summarized by van Kuijk and colleagues [100] revealed another problem. Whole tissue blocks were used in $40 \%$ of studies, the rest was performed using either biopsy or tissue microarray (TMA). Although there are several advantages favoring the utilization of TMAs in IHC, this approach can lead to loss of important information due to intratumoral heterogeneity, especially when only one TMA core is included in the staining. This is supported by the observation that only $4.7 \%$ of breast cancer TMA cores were found CA IXpositive compared to $18.1 \%$ of whole tissue blocks [138]. reaction was visualized using $\mathrm{DAB}$ as a chromogen. Sections were counterstained with Mayer hematoxylin. A, C Original magnification $\times 100$. B, D Original magnification $\times 400$

Another factor negatively impacting results of IHC lies in omitting perinecrotic regions from TMA construction. It is well-known that intratumoral hypoxia is reflected histologically by the presence of necrosis, which is considered a bad prognostic factor in cancer patients [176, 177]. Staining pattern of the hypoxia-induced CA IX is very heterogeneous, often confined to perinecrotic areas, and therefore, use of TMAs devoid of necrotic regions is not appropriate for the CA IX IHC analysis. The same is true for other molecules related to cancer metabolism, which is a phenomenon with inherent heterogeneity.

In case of TMA, the best way how to overcome the problem of tumor tissue heterogeneity is to analyze multiple cores. According to several studies, up to $98 \%$ consistency with the results from full-block sections can be achieved when at least three TMA cores are stained. Lower 
Table 2 Evaluation of selected clinical studies (first author, year) with respect to their reproducibility potential. The studies were clustered according to organ of tumor origin and subjected to evaluation of the primary antibody quality based on the results of our current validation (antibody), relevance of tissue specimens for investigation of tumor heterogeneity (tissue), and methodology judged according to the available data on antigen retrieval, staining kits, and positive/ negative control (IHC staining). The "reproducibility index" (RI) was calculated as a sum of stars awarded to each variable (Antibody, Tissue, IHC staining) with the maximum of 7 points per study. Three stars were used when a sufficient description (clone name, source, dilution) of primary anti-CA IX antibody was mentioned within a particular study. Tissue sample was evaluated using either T/TMA $\geqq 3$ (for whole tissue or TMA $\geqq 3$ cores, 1 star) or B/TMA $<3$ (for biopsy or TMA $<3$ cores, no star). IHC staining was evaluated regarding the available data about antigen retrieval, staining kit, and positive/negative control (maximum 3 stars). Hazard ratio (HR) with corresponding 95\% CI as well as Newcastle-Ottawa score (NOS) quality assessment was adopted from van Kuijk et al., Front Oncol 2016 [100]

\begin{tabular}{|c|c|c|c|c|c|c|}
\hline \multicolumn{7}{|l|}{ Brain } \\
\hline Study & Antibody & Tissue & IHC staining & RI & HR (95\% CI)/endpoint & NOS \\
\hline Dungwa, 2012 [102] & M75** & $\mathrm{T} / \mathrm{TMA} \geqq 3 *$ & $* *$ & 5 & $\begin{array}{l}1.71(0.80-3.65) / \mathrm{OS} 1.73 \\
\quad(0.83-3.59) / \mathrm{PFS}\end{array}$ & 7 \\
\hline Korkolopoulou, 2007 [103] & $\mathrm{M} 75 * *^{\mathrm{R}}$ & $\mathrm{T} / \mathrm{TMA} \geqq 3 *$ & $* * *$ & $6^{*}$ & $4.04(2.38-6.85) / \mathrm{OS}$ & 6 \\
\hline Ameis, 2015 [104] & M75*** & $\mathrm{T} / \mathrm{TMA} \geqq 3 *$ & $* *$ & 6 & $15.7(2.04-121.1) / \mathrm{OS}$ & 5 \\
\hline Jarvela, 2008 [105] & M75*** & $\mathrm{B} / \mathrm{TMA}<3$ & $* *$ & 5 & $2.98(1.67-5.30) / \mathrm{OS}$ & 5 \\
\hline Nordfors, 2010 [106] & M75*** & $\mathrm{B} / \mathrm{TMA}<3$ & $* *$ & 5 & $3.96(1.20-13.0) / \mathrm{OS}$ & 4 \\
\hline Haapasalo, 2006 [107] & M75*** & $\mathrm{B} / \mathrm{TMA}<3$ & $* * *$ & 6 & $1.40(1.01-1.94) / 0 \mathrm{~S}$ & 3 \\
\hline Erpolat, 2013 [108] & Abcam $* *$ & $\mathrm{~T} / \mathrm{TMA} \geqq 3 *$ & $* * *$ & 6 & $2.34(1.47-3.71) / \mathrm{OS}$ & 5 \\
\hline Proescholdt, 2012 [109] & Novus $* *$ & $\mathrm{~B} / \mathrm{TMA}<3$ & $\mathrm{R}$ & $2 *$ & $3.67(2.03-6.61) / \mathrm{OS}$ & 6 \\
\hline Yoo, 2010 [110] & Novus $* *$ & $\mathrm{~T} / \mathrm{TMA} \geqq 3 *$ & $* *$ & 5 & $2.27(1.29-4.00) / \mathrm{OS}$ & 4 \\
\hline Abraham, 2012 [111] & $\begin{array}{l}\dagger \text { Santa Cruz } \\
* *\end{array}$ & $\mathrm{~T} / \mathrm{TMA} \geqq 3 *$ & $* * *$ & 6 & $\begin{array}{l}1.59(0.35-7.15) / \mathrm{OS} 1.65 \\
(0.50-5.48) / \mathrm{PFS}\end{array}$ & 5 \\
\hline Abraham, 2012 [111] & $\begin{array}{l}\dagger \text { Santa Cruz } \\
* *\end{array}$ & $\mathrm{~T} / \mathrm{TMA} \geqq 3 *$ & $* * *$ & 6 & $\begin{array}{l}0.19(0.02-1.61) / \mathrm{OS} 0.47 \\
\quad(0.06-3.69) / \mathrm{PFS}\end{array}$ & 5 \\
\hline Jensen, 2012 [112] & $\begin{array}{l}\dagger \text { Santa Cruz } \\
* *\end{array}$ & $\mathrm{~T} / \mathrm{TMA} \geqq 3 *$ & $* * *$ & 6 & $\begin{array}{l}1.10(0.62-1.95) / \mathrm{OS} 1.31 \\
\quad(0.64-2.66) / \mathrm{PFS}\end{array}$ & 4 \\
\hline Sooman, 2015 [113] & $\begin{array}{l}\text { Strategic Diagnostics } \\
* * *\end{array}$ & $\mathrm{~B} / \mathrm{TMA}<3$ & $\mathrm{R}$ & $3 *$ & $3.35(1.55-7.22) / \mathrm{OS}$ & 4 \\
\hline Flynn, 2008 [114] & $?$ & $\mathrm{~T} / \mathrm{TMA} \geqq 3 *$ & $* * *$ & 4 & $1.19(0.70-2.03) / \mathrm{OS}$ & 4 \\
\hline Preuser, 2005 [115] & $?$ & $\mathrm{~T} / \mathrm{TMA} \geqq 3 *$ & $* *$ & 3 & Inadequate data/OS & - \\
\hline \multicolumn{7}{|l|}{ Pancreas } \\
\hline Study & Antibody & Tissue & IHC staining & RI & HR (95\% CI)/endpoint & NOS \\
\hline Couvelard, 2005 [116] & $\mathrm{M} 75 *^{\mathrm{a}}$ & $\mathrm{T} / \mathrm{TMA} \geqq 3 *$ & $* * *$ & 5 & $35.3(10.3-121) / \mathrm{OS}$ & 7 \\
\hline Couvelard, 2005 [117] & $\mathrm{M} 75 *^{\mathrm{a}}$ & $\mathrm{T} / \mathrm{TMA} \geqq 3 *$ & $* * *$ & 5 & $1.86(0.90-3.84) / \mathrm{OS}$ & 7 \\
\hline Chang, 2010 [118] & $\mathrm{M} 75 * *^{\mathrm{R}}$ & $\mathrm{T} / \mathrm{TMA} \geqq 3 *$ & $* *$ & $5^{*}$ & $0.99(0.54-1.80) / \mathrm{OS}$ & 4 \\
\hline Hiraoka, 2010 [119] & M75*** & $\mathrm{T} / \mathrm{TMA} \geqq 3 *$ & $* * *$ & 7 & $\begin{array}{l}1.33(0.97-1.84) / \mathrm{DFS} 1.49 \\
(1.07-2.07) / \mathrm{DSS}\end{array}$ & 3 \\
\hline $\mathrm{Li}, 2016[120]$ & Abcam $* *$ & $\mathrm{~T} / \mathrm{TMA} \geqq 3 *$ & $* * *$ & 6 & $2.24(1.26-3.96) / \mathrm{OS}$ & 7 \\
\hline Schmitt, 2009 [121] & Abcam $* * *$ & $\mathrm{~B} / \mathrm{TMA}<3$ & $* * *$ & 6 & $7.36(3.11-17.4) / \mathrm{DFS}$ & 3 \\
\hline $\mathrm{Yu}, 2015$ [122] & Epitomics $* *$ & $\mathrm{~T} / \mathrm{TMA} \geqq 3 *$ & $* * *$ & 6 & $1.07(0.63-1.81) / \mathrm{OS}$ & 6 \\
\hline \multicolumn{7}{|l|}{ Breast } \\
\hline Study & Antibody & Tissue & IHC staining & RI & HR (95\% CI)/endpoint & NOS \\
\hline Trastour, 2007 [123] & M75*** & $\mathrm{T} / \mathrm{TMA} \geqq 3 *$ & $* *$ & 6 & $\begin{array}{l}\text { Inadequate data/OS } 2.57(1.39- \\
\text { 4.77)/DFS } 2.70(1.20-6.10) / \\
\text { MFS }\end{array}$ & 7 \\
\hline Hussain, 2007 [124] & M75*** & $\mathrm{T} / \mathrm{TMA} \geqq 3 *$ & $* * *$ & 7 & $2.63(1.21-5.70) / \mathrm{OS}$ & 6 \\
\hline Betof, 2012 [125] & $\mathrm{M} 75 * *^{\mathrm{a}}$ & $\mathrm{B} / \mathrm{TMA}<3$ & $* * *$ & 5 & $\begin{array}{l}2.20(1.10-4.41) / \mathrm{OS} 1.88 \\
\quad(1.13-3.13) / \mathrm{PFS}\end{array}$ & 5 \\
\hline Aomatsu, 2014 [126] & $\mathrm{M} 75 * *^{\mathrm{a}}$ & $\mathrm{T} / \mathrm{TMA} \geqq 3 *$ & $* *$ & 5 & $4.44(1.80-10.9) / \mathrm{DFS}$ & 4 \\
\hline Lou, 2011 [127] & $\mathrm{M} 75 * *^{\mathrm{R}}$ & $\mathrm{B} / \mathrm{TMA}<3$ & $*^{\mathrm{R}}$ & $3 * *$ & $\begin{array}{l}1.93(1.65-2.26) / \mathrm{DFS} 2.28 \\
(1.89-2.73) / \mathrm{DSS} 2.06(1.74- \\
2.43) / \mathrm{MFS}\end{array}$ & 4 \\
\hline Tan, 2009 [128] & M75 *** & $\mathrm{B} / \mathrm{TMA}<3$ & $* *$ & 5 & $\begin{array}{l}5.02(3.01-8.38) / \mathrm{OS} 1.89 \\
\quad(1.19-3.00) / \mathrm{DFS}\end{array}$ & 4 \\
\hline
\end{tabular}


Table 2 (continued)

\begin{tabular}{|c|c|c|c|c|c|c|}
\hline Brennan, 2006 [129] & $\mathrm{M} 75 * *^{\mathrm{a}}$ & $\mathrm{B} / \mathrm{TMA}<3$ & $* * *$ & 5 & $\begin{array}{l}1.91(1.12-3.26) / O S 1.99(1.30- \\
3.05) / D F S 1.85(1.19-2.87) / \\
\text { DSS }\end{array}$ & 3 \\
\hline Generali, 2006 [130] & M75*** & $\mathrm{B} / \mathrm{TMA}<3$ & $* * *$ & 6 & $\begin{array}{l}1.93(0.86-4.33) / \mathrm{OS} 1.67 \\
(0.89-3.14) / \mathrm{DFS}\end{array}$ & 3 \\
\hline Kyndi, 2008 [131] & $\mathrm{M} 75 * *^{\mathrm{R}}$ & $\mathrm{B} / \mathrm{TMA}<3$ & $* * *$ & $5^{*}$ & $\begin{array}{l}1.30(1.06-1.60) / \mathrm{OS} 1.28(0.82- \\
2.01) / \mathrm{LC} 1.29(1.02-1.62) / \mathrm{DSS} \\
1.23(0.98-1.54) / \mathrm{MFS}\end{array}$ & 3 \\
\hline Neumeister, 2012 [132] & $\mathrm{M} 75 * * *$ & $\mathrm{~B} / \mathrm{TMA}<3$ & $* * *$ & 6 & $2.21(1.20-4.09) / \mathrm{DSS}$ & 3 \\
\hline Neumeister, 2012 [132] & $\mathrm{M} 75 * * *$ & $\mathrm{~B} / \mathrm{TMA}<3$ & $* * *$ & 6 & $1.36(0.75-2.47) / \mathrm{DSS}$ & 3 \\
\hline Tomes, 2003 [88] & $\mathrm{M} 75 * * *$ & $\mathrm{~T} / \mathrm{TMA} \geqq 3 *$ & $* * *$ & 7 & $0.78(0.31-1.94) / \mathrm{OS}$ & 2 \\
\hline Doyen, 2014 [133] & $\mathrm{M} 75 * * *$ & $\mathrm{~T} / \mathrm{TMA} \geqq 3 *$ & $* *$ & 6 & Inadequate data/MFS & - \\
\hline Pinheiro, 2011 [134] & Abcam $* * *$ & $\mathrm{~B} / \mathrm{TMA}<3$ & $* * *$ & 6 & $2.22(0.79-6.20) / \mathrm{DFS}$ & 7 \\
\hline Garcia, 2007 [135] & Abcam $* * *$ & $\mathrm{~B} / \mathrm{TMA}<3$ & $* *$ & 5 & $1.55(1.19-2.01) / \mathrm{OS}$ & 4 \\
\hline Bane, 2014 [136] & Abcam $* *$ & $\mathrm{~T} / \mathrm{TMA} \geqq 3 *$ & $*$ & 4 & $1.53(0.84-2.77) / \mathrm{LC}$ & 4 \\
\hline Kim H, 2014 [137] & Abcam ** & $\mathrm{B} / \mathrm{TMA}<3$ & $* * *$ & 5 & $1.43(0.80-2.56) / \mathrm{OS}$ & 4 \\
\hline Lancashire, 2010 [138] & Abcam $* * *$ & $\begin{array}{l}\mathrm{B} / \mathrm{TMA}<3 \\
\mathrm{~T} / \mathrm{TMA} \geqq 3 *\end{array}$ & $* * *$ & $6^{*}$ & $\begin{array}{l}\text { Inadequate data/OS } 2.19 \\
(0.78-6.16) / \mathrm{DFS}\end{array}$ & 3 \\
\hline Kornegoor, 2012 [139] & Abcam ** & $\mathrm{T} / \mathrm{TMA} \geqq 3 *$ & $* * *$ & 6 & $0.62(0.19-2.11) / \mathrm{OS}$ & 3 \\
\hline Noh, 2014 [140] & Abcam $* *$ & $\mathrm{~B} / \mathrm{TMA}<3$ & $* * *$ & 5 & $\begin{array}{l}\text { Inadequate data/OS inadequate } \\
\text { data/DFS }\end{array}$ & - \\
\hline Currie, 2013 [141] & Novus $* *$ & $\mathrm{~T} / \mathrm{TMA} \geqq 3 *$ & $* * *$ & 6 & $\begin{array}{l}1.05(0.48-2.26) / \mathrm{OS} 0.77 \\
(0.39-1.55) / \mathrm{DFS}\end{array}$ & 6 \\
\hline Deb, 2014 [142] & Novus $* *$ & $\mathrm{~B} / \mathrm{TMA}<3$ & $* *$ & 4 & $2.20(0.80-5.70) / \mathrm{OS}$ & 3 \\
\hline Beketic-Oreskovic, 2011 [143] & $\begin{array}{l}\dagger \text { Santa Cruz } \\
* *\end{array}$ & $\mathrm{~T} / \mathrm{TMA} \geqq 3 *$ & $* * *$ & 6 & $4.78(2.15-10.6) / \mathrm{OS}$ & 7 \\
\hline Kaya, 2012 [144] & $\begin{array}{l}\dagger \text { Santa Cruz } \\
* * *\end{array}$ & $\mathrm{~T} / \mathrm{TMA} \geqq 3 *$ & $* * *$ & 7 & $\begin{array}{l}2.82(1.71-4.64) / \mathrm{OS} 0.84 \\
\quad(0.53-1.33) / \mathrm{DFS}\end{array}$ & 5 \\
\hline \multicolumn{7}{|l|}{ Head and neck } \\
\hline \multirow[t]{2}{*}{ Study } & Reproducibility index & & & & HR (95\% CI)/endpoint & NOS \\
\hline & Antibody & Tissue & IHC staining & RI & & \\
\hline Silva, 2010 [145] & $\mathrm{M} 75 * * *$ & $\mathrm{~B} / \mathrm{TMA}<3$ & $* * *$ & 6 & $\begin{array}{l}5.21(2.48-10.9) / \mathrm{LC} 5.08 \\
\quad(2.53-10.2) / \mathrm{DSS}\end{array}$ & 7 \\
\hline Hui, 2002 [87] & M75** & $\mathrm{B} / \mathrm{TMA}<3$ & $* * *$ & 5 & $\begin{array}{l}1.39(0.64-3.01) / \mathrm{OS} 1.28 \\
(0.65-2.52) / \mathrm{PFS}\end{array}$ & 6 \\
\hline Koukourakis, 2001 [146] & $\mathrm{M} 75 * * *$ & $\mathrm{~B} / \mathrm{TMA}<3$ & $* *$ & 5 & $\begin{array}{l}2.47(1.23-4.98) / \mathrm{OS} 3.05 \\
\quad(1.46-6.35) / \mathrm{LC}\end{array}$ & 6 \\
\hline Koukourakis, 2006 [147] & $\mathrm{M} 75 * *$ & $\mathrm{~B} / \mathrm{TMA}<3$ & $* *$ & 4 & $\begin{array}{l}1.79(1.21-2.64) / \mathrm{OS} 1.84 \\
\quad(1.24-2.75) / \mathrm{LC}\end{array}$ & 6 \\
\hline Bernstein, 2015 [148] & $\mathrm{M} 75 * * *$ & $\mathrm{~B} / \mathrm{TMA}<3$ & $* * *$ & 6 & $\begin{array}{l}1.67(0.77-3.61) / \mathrm{LC} 2.31 \\
(1.04-5.12) \mathrm{DSS}\end{array}$ & 5 \\
\hline Choi, 2008 [149] & $\mathrm{M} 75 * * *$ & $\mathrm{~T} / \mathrm{TMA} \geqq 3$ & $* *$ & 6 & $1.91(0.77-4.71) / \mathrm{OS}$ & 5 \\
\hline De Schutter, 2005 [150] & M75 *** & $\mathrm{B} / \mathrm{TMA}<3$ & $* * *$ & 6 & $\begin{array}{l}1.68(0.94-2.99) / \mathrm{DFS} 1.72 \\
(0.94-3.14) / \mathrm{LC}\end{array}$ & 5 \\
\hline Douglas, 2013 [151] & $\mathrm{M} 75 * * *$ & $\mathrm{~B} / \mathrm{TMA}<3$ & $* * *$ & 6 & $1.76(0.87-3.56) / \mathrm{LC}$ & 5 \\
\hline Heo, 2012 [152] & $\mathrm{M} 75 * * *$ & $\mathrm{~T} / \mathrm{TMA} \geqq 3 *$ & $* *$ & 6 & 4.95 (1.39-17.5)/DFS & 5 \\
\hline Kim S, 2007 [153] & $\mathrm{M} 75 * *^{\mathrm{a}}$ & $\mathrm{T} / \mathrm{TMA} \geqq 3 *$ & $* * *$ & 6 & $\begin{array}{l}2.99(1.39-6.45) / \mathrm{OS} 1.76 \\
\quad(0.89-3.51) / \mathrm{DFS}\end{array}$ & 5 \\
\hline Perez-Sayans, 2012 [154] & $\mathrm{M} 75 * * *$ & $\mathrm{~B} / \mathrm{TMA}<3$ & $* * *$ & 6 & $1.36(0.43-4.26) / \mathrm{OS}$ & 4 \\
\hline Wachters, 2013 [155] & $\mathrm{M} 75 * * *$ & $\mathrm{~T} / \mathrm{TMA} \geqq 3 *$ & $* *$ & 6 & $\begin{array}{l}0.83(0.31-2.22) / \mathrm{OS} 0.34 \\
\quad(0.04-2.58) / \mathrm{LC}\end{array}$ & 4 \\
\hline Eriksen, 2007 [156] & M75*** & $\mathrm{T} / \mathrm{TMA} \geqq 3 *$ & $* * *$ & 7 & $1.10(0.74-1.64) / \mathrm{LC}$ & 3 \\
\hline Le, 2005 [157] & $\mathrm{M} 75 * *^{\mathrm{R}}$ & $\mathrm{B} / \mathrm{TMA}<3$ & $*^{\mathrm{R}}$ & $3^{* *}$ & $\begin{array}{l}1.73(0.91-3.29) / \mathrm{OS} 2.21 \\
\quad(1.11-4.39) / \mathrm{DFS}\end{array}$ & 3 \\
\hline Nordsmark, 2007 [158] & $\mathrm{M} 75 * *^{\mathrm{a}}$ & $\mathrm{T} / \mathrm{TMA} \geqq 3 *$ & $* *$ & 5 & $1.27(0.62-2.62) / \mathrm{LC}$ & 2 \\
\hline
\end{tabular}


Table 2 (continued)

\begin{tabular}{|c|c|c|c|c|c|c|}
\hline Winter, 2006 [159] & $\mathrm{M} 75 * *^{\mathrm{R}}$ & $\mathrm{B} / \mathrm{TMA}<3$ & $* * *$ & $5 *$ & $\begin{array}{l}\text { Inadequate data/OS inadequate } \\
\text { data/DFS inadequate data/DSS }\end{array}$ & - \\
\hline Koukourakis, 2008 [160] & Abcam ** & $\begin{aligned} \mathrm{T} / \mathrm{TMA} & \geqq 3 * \mathrm{~B} / \\
\mathrm{TMA} & <3\end{aligned}$ & $* *$ & $4 *$ & $\begin{array}{l}1.64(0.62-4.32) / \mathrm{OS} 4.41 \\
\quad(1.72-11.3) / \mathrm{LC}\end{array}$ & 5 \\
\hline Kondo, 2011 [161] & Abcam $* *$ & $\mathrm{~T} / \mathrm{TMA} \geqq 3 *$ & $* *$ & 5 & $3.36(0.97-11.7) / \mathrm{OS}$ & 4 \\
\hline Brockton, 2011 [162] & Abcam $* *$ & $\mathrm{~T} / \mathrm{TMA} \geqq 3 *$ & $* *$ & 5 & $1.20(0.46-3.12) / \mathrm{OS}$ & 4 \\
\hline Brockton, 2012 [163] & $\begin{array}{l}\text { Abcam } * * * \\
\text { M75** } *\end{array}$ & $\mathrm{~T} / \mathrm{TMA} \geqq 3 *$ & $* * *$ & 7 & $2.04(0.76-5.49) / \mathrm{DSS}$ & 3 \\
\hline Zheng, 2015 [164] & Cell Signaling * & $\mathrm{B} / \mathrm{TMA}<3$ & $* *$ & 3 & $4.27(2.37-7.72) / \mathrm{OS}$ & 4 \\
\hline Sakata, 2008 [165] & Novus $*$ & $\mathrm{~B} / \mathrm{TMA}<3$ & $\mathbf{R}$ & $1 *$ & $0.91(0.32-2.61) / \mathrm{LC}$ & 7 \\
\hline Chen, 2014 [166] & Novus $* *$ & $\mathrm{~B} / \mathrm{TMA}<3$ & $* *$ & 4 & $\begin{array}{l}1.97(1.02-3.81) / \mathrm{OS} 1.96(1.01- \\
3.78) / \mathrm{LC} 1.96(1.02-3.76) / \\
\text { MFS } 2.01(1.05-3.86) / \mathrm{PFS}\end{array}$ & 6 \\
\hline Hwa, 2015 [167] & Novus $* *$ & $\mathrm{~B} / \mathrm{TMA}<3$ & $* *$ & 4 & $0.29(0.05-1.77) / \mathrm{DSS}$ & 4 \\
\hline Kwon, 2015 [168] & Novus $* *$ & $\mathrm{~B} / \mathrm{TMA}<3$ & $* *$ & 4 & $8.65(1.01-74.1) / \mathrm{LC}$ & 4 \\
\hline Han, 2012 [169] & $\begin{array}{l}\mathrm{R} \& \mathrm{D} \text { Systems } \\
* * *\end{array}$ & $\mathrm{~B} / \mathrm{TMA}<3$ & * & 4 & $\begin{array}{l}0.65(0.12-3.67) / \mathrm{OS} 0.50 \\
\quad(0.80-3.15) / \mathrm{DFS}\end{array}$ & 6 \\
\hline Roh, 2008 [170] & $\begin{array}{l}\text { R\&D Systems } \\
* * *\end{array}$ & $\mathrm{~B} / \mathrm{TMA}<3$ & - & 3 & $\begin{array}{c}0.71(0.23-2.22) / \mathrm{OS} 1.77(0.56- \\
5.56) / \mathrm{DFS} 1.20(0.34-4.18) / \mathrm{LC}\end{array}$ & 5 \\
\hline Roh, 2009 [171] & $\begin{array}{l}\text { R\&D Systems } \\
* * *\end{array}$ & $\mathrm{~B} / \mathrm{TMA}<3$ & - & 3 & $\begin{array}{l}1.09(0.43-2.76) / \mathrm{LC} 2.13 \\
(0.74-6.13) / \mathrm{DSS}\end{array}$ & 4 \\
\hline Yang, 2015 [172] & $†$ Santa Cruz $* *$ & $\mathrm{~B} / \mathrm{TMA}<3$ & $* *$ & 4 & $1.76(1.07-2.87) / \mathrm{OS}$ & 7 \\
\hline Eckert, 2010 [173] & $\begin{array}{l}\dagger \text { Santa Cruz } \\
* * *\end{array}$ & $\mathrm{~B} / \mathrm{TMA}<3$ & * & 4 & $1.34(0.65-2.76) / \mathrm{OS}$ & 5 \\
\hline Jonathan, 2006 [174] & $?$ & $\mathrm{~B} / \mathrm{TMA}<3$ & $* *$ & 2 & $\begin{array}{l}0.27(0.08-0.93) / \mathrm{LC} 0.27 \\
\quad(0.09-0.83) / \mathrm{MFS}\end{array}$ & 2 \\
\hline Rademakers, 2013 [175] & $?$ & $\mathrm{~B} / \mathrm{TMA}<3$ & $* *$ & 2 & $\begin{array}{l}0.70(0.50-1.10) / \mathrm{OS} 0.50 \\
\quad(0.20-1.10) / \mathrm{LC} 0.70(0.40- \\
1.50) / \mathrm{MFS}\end{array}$ & 1 \\
\hline
\end{tabular}

${ }^{\mathrm{R}}$ Relevant information was supplied as a reference

${ }^{\dagger}$ Antibody no longer available

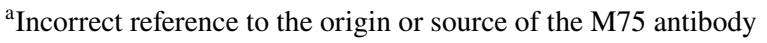

? no data available

concordance is observed with only 1 or 2 cores (as reviewed in [178]). In meta-analysis presented by van Kuijk et al. (2016), 3 or more cores were used in 41.7\% of TMA-based IHC studies, and less than three cores were used in 38.3\% cases, whereas in the rest of the studies, tissue selection was not properly defined.

While insufficient identification and quality of antibodies clearly contribute to replication crisis in general, use of inappropriate tissue material particularly jeopardizes understanding of tumor heterogeneity including its metabolic aspects.

Deeper analysis of the 147 clinical studies mentioned in the meta-analysis by van Kuijk and colleagues revealed some general weak points frequently occurring in multiple clinical studies, e.g., insufficient description of antibody (clone name, source, dilution) and staining procedure (antigen retrieval, staining kit, positive/negative control), and tissue selection (whole tissue block vs TMA). As shown in Table 2, reevaluation of these studies with respect to their reliability and reproducibility using a "reproducibility index" (RI) based on inspection of the antibody properties and staining methodology showed remarkable discrepancies with an established Newcastle-Ottawa scale (NOS) (which was used by van Kuijk and colleagues) $[100,179]$. The traditional NOS evaluation system puts emphasis on the scoring methodology, the cohort characteristics, and the disease outcome, while it ignores the abovementioned important aspects of IHC studies, such as precise description of antibody, type of tissue specimen, and details of staining procedure. This can significantly impact on the interpretation of data and ultimately affect their translation to clinical side.

\section{Conclusion}

Understanding physiological and molecular mechanisms of cancer metabolic plasticity requires not only technologically advanced high-throughput metabolomic, proteomic, and 
genomic approaches, but also classical methods of molecular and cellular biology. The latter approaches have already uncovered spectrum of molecules and pathways driving metabolic reprogramming that facilitates survival and proliferation of cancer cells in the process of tumor tissue growth as well as during metastatic dissemination. These molecules include metabolic enzymes, transporters, and regulators that often display highly heterogeneous expression pattern reflecting dynamically changing selection-adaptation forces in tumor microenvironment. Using the example of CA IX, we provide a basic insight into the interplay of these molecules. Through the validation of CA IX-specific antibodies, we explain that well-characterized research tools/materials and sufficient technical details are important prerequisites for acquisition of reliable/reproducible data and for building of new knowledge translatable from bench to bedside.

Supplementary Information The online version contains supplementary material available at https://doi.org/10.1007/s10555-021-10011-5.

Funding The authors' research is supported by The George Schwab and Leona Lauder Foundation and by grants from the Slovak Research and Development Agency (APVV-19-0098), Slovak Scientific Grant Agency (VEGA 2/0076/20 and VEGA 2/0074/20), and European Regional Development Fund (OPVaI-VA/DP/2018/1.2.1-08, ITMS 313011V344).

\section{Declarations}

Competing interests SP, MZ, and MT are co-inventors of IP related to CA IX. The remaining authors declare no conflicts of interest.

Open Access This article is licensed under a Creative Commons Attribution 4.0 International License, which permits use, sharing, adaptation, distribution and reproduction in any medium or format, as long as you give appropriate credit to the original author(s) and the source, provide a link to the Creative Commons licence, and indicate if changes were made. The images or other third party material in this article are included in the article's Creative Commons licence, unless indicated otherwise in a credit line to the material. If material is not included in the article's Creative Commons licence and your intended use is not permitted by statutory regulation or exceeds the permitted use, you will need to obtain permission directly from the copyright holder. To view a copy of this licence, visit http://creativecommons.org/licenses/by/4.0/.

\section{References}

1. Vander Heiden, M. G., Cantley, L. C., \& Thompson, C. B. (2009). Understanding the Warburg effect: The metabolic requirements of cell proliferation. Science, 324(5930), 1029-1033. https://doi. org/10.1126/science.1160809

2. Levine, A. J., \& Puzio-Kuter, A. M. (2010). The control of the metabolic switch in cancers by oncogenes and tumor suppressor genes. Science, 330(6009), 1340-1344. https://doi.org/10.1126/ science. 1193494
3. Nagarajan, A., Malvi, P., \& Wajapeyee, N. (2016). Oncogenedirected alterations in cancer cell metabolism. Trends Cancer, 2(7), 365-377. https://doi.org/10.1016/j.trecan.2016.06.002

4. Hsieh, A. L., Walton, Z. E., Altman, B. J., Stine, Z. E., \& Dang, C. V. (2015). MYC and metabolism on the path to cancer. Seminars in Cell \& Developmental Biology, 43, 11-21. https:// doi.org/10.1016/j.semcdb.2015.08.003

5. Mukhopadhyay, S., Vander Heiden, M. G., \& McCormick, F. (2021). The metabolic landscape of RAS-driven cancers from biology to therapy. Nat Cancer, 2(3), 271-283. https://doi.org/ 10.1038/s43018-021-00184-x

6. Schulze, A., \& Harris, A. L. (2012). How cancer metabolism is tuned for proliferation and vulnerable to disruption. Nature, 491(7424), 364-373. https://doi.org/10.1038/nature11706

7. Sciacovelli, M., \& Frezza, C. (2016). Oncometabolites: Unconventional triggers of oncogenic signalling cascades. Free Radical Biology \& Medicine, 100, 175-181. https://doi.org/10. 1016/j.freeradbiomed.2016.04.025

8. Schmidt, C., Sciacovelli, M., \& Frezza, C. (2020). Fumarate hydratase in cancer: A multifaceted tumour suppressor. Seminars in Cell \& Developmental Biology, 98, 15-25. https://doi. org/10.1016/j.semcdb.2019.05.002

9. Lloyd, M. C., Cunningham, J. J., Bui, M. M., Gillies, R. J., Brown, J. S., \& Gatenby, R. A. (2016). Darwinian dynamics of intratumoral heterogeneity: Not solely random mutations but also variable environmental selection forces. Cancer Research, 76(11), 3136-3144. https://doi.org/10.1158/00085472.CAN-15-2962

10. Gillies, R. J., Brown, J. S., Anderson, A. R. A., \& Gatenby, R. A. (2018). Eco-evolutionary causes and consequences of temporal changes in intratumoural blood flow. Nature Reviews Cancer, 18(9), 576-585. https://doi.org/10.1038/ s41568-018-0030-7

11. Elia, I., \& Haigis, M. C. (2021). Metabolites and the tumour microenvironment: From cellular mechanisms to systemic metabolism. Nature Metabolism, 3(1), 21-32. https://doi.org/ 10.1038/s42255-020-00317-z

12. Harris, A. L. (2002). Hypoxia-A key regulatory factor in tumour growth. Nature Reviews Cancer, 2(1), 38-47. https://doi.org/10. 1038/nrc704

13. Ratcliffe, P. J. (2013). Oxygen sensing and hypoxia signalling pathways in animals: The implications of physiology for cancer. Journal of Physiology, 591(8), 2027-2042. https://doi.org/10. 1113/jphysiol.2013.251470

14. Semenza, G. L. (2012). Hypoxia-inducible factors: Mediators of cancer progression and targets for cancer therapy. Trends in Pharmacological Sciences, 33(4), 207-214. https://doi.org/10. 1016/j.tips.2012.01.005

15. Wouters, B. G., \& Koritzinsky, M. (2008). Hypoxia signalling through mTOR and the unfolded protein response in cancer. Nature Reviews Cancer, 8(11), 851-864. https://doi.org/10.1038/ $\operatorname{nrc} 2501$

16. Sebestyen, A., Kopper, L., Danko, T., \& Timar, J. (2021). Hypoxia signaling in cancer: From basics to clinical practice. Pathology Oncology Research, 27, 1609802. https://doi.org/10. 3389/pore.2021.1609802

17. Li, F., \& Simon, M. C. (2020). Cancer cells don't live alone: Metabolic communication within tumor microenvironments. Developmental Cell, 54(2), 183-195. https://doi.org/10.1016/j. devcel.2020.06.018

18. Corbet, C., \& Feron, O. (2017). Tumour acidosis: From the passenger to the driver's seat. Nature Reviews Cancer, 17(10), 577-593. https://doi.org/10.1038/nrc.2017.77

19. Sonveaux, P., Vegran, F., Schroeder, T., Wergin, M. C., Verrax, J., Rabbani, Z. N., et al. (2008). Targeting lactate-fueled respiration selectively kills hypoxic tumor cells in mice. The Journal 
of Clinical Investigation, 118(12), 3930-3942. https://doi.org/ 10.1172/JCI36843

20. Payen, V. L., Mina, E., Van Hee, V. F., Porporato, P. E., \& Sonveaux, P. (2020). Monocarboxylate transporters in cancer. Mol Metab, 33, 48-66. https://doi.org/10.1016/j.molmet.2019.07.006

21. Swietach, P. (2019). What is $\mathrm{pH}$ regulation, and why do cancer cells need it? Cancer and Metastasis Reviews, 38(1-2), 5-15. https://doi.org/10.1007/s10555-018-09778-x

22. Wojtkowiak, J. W., Verduzco, D., Schramm, K. J., \& Gillies, R. J. (2011). Drug resistance and cellular adaptation to tumor acidic pH microenvironment. Molecular Pharmaceutics, 8(6), 2032-2038. https://doi.org/10.1021/mp200292c

23. Schonichen, A., Webb, B. A., Jacobson, M. P., \& Barber, D. L. (2013). Considering protonation as a posttranslational modification regulating protein structure and function. Annual Review of Biophysics, 42, 289-314. https://doi.org/10.1146/annurev-bioph ys-050511-102349

24. Dixon, S. J., Lemberg, K. M., Lamprecht, M. R., Skouta, R., Zaitsev, E. M., Gleason, C. E., et al. (2012). Ferroptosis: An iron-dependent form of nonapoptotic cell death. Cell, 149(5), 1060-1072. https://doi.org/10.1016/j.cell.2012.03.042

25. Chafe, S. C., Vizeacoumar, F. S., Venkateswaran, G., Nemirovsky, O., Awrey, S., Brown, W. S., et al. (2021). Genome-wide synthetic lethal screen unveils novel CAIX-NFS1/xCT axis as a targetable vulnerability in hypoxic solid tumors. Sci $A d v, 7(35)$. https://doi.org/10.1126/sciadv.abj0364.

26. Korenchan, D. E., \& Flavell, R. R. (2019). Spatiotemporal pH heterogeneity as a promoter of cancer progression and therapeutic resistance. Cancers (Basel), 11(7). https://doi.org/10.3390/ cancers11071026.

27. Mason, J. A., Hagel, K. R., Hawk, M. A., \& Schafer, Z. T. (2017). Metabolism during ECM detachment: Achilles heel of cancer cells? Trends Cancer, 3(7), 475-481. https://doi.org/10.1016/j. trecan.2017.04.009

28. Sciacovelli, M., \& Frezza, C. (2017). Metabolic reprogramming and epithelial-to-mesenchymal transition in cancer. FEBS Journal, 284(19), 3132-3144. https://doi.org/10.1111/febs. 14090

29. Mosier, J. A., Schwager, S. C., Boyajian, D. A., \& Reinhart-King, C. A. (2021). Cancer cell metabolic plasticity in migration and metastasis. Clinical \& Experimental Metastasis, 38(4), 343-359. https://doi.org/10.1007/s10585-021-10102-1

30. Chen, Y., McAndrews, K. M., \& Kalluri, R. (2021). Clinical and therapeutic relevance of cancer-associated fibroblasts. Nature Reviews. Clinical Oncology. https://doi.org/10.1038/ s41571-021-00546-5

31. Fiaschi, T., Marini, A., Giannoni, E., Taddei, M. L., Gandellini, P., De Donatis, A., et al. (2012). Reciprocal metabolic reprogramming through lactate shuttle coordinately influences tumorstroma interplay. Cancer Research, 72(19), 5130-5140. https:// doi.org/10.1158/0008-5472.CAN-12-1949

32. Hulikova, A., \& Swietach, P. (2014). Rapid CO2 permeation across biological membranes: Implications for $\mathrm{CO} 2$ venting from tissue. The FASEB Journal, 28(7), 2762-2774. https://doi.org/10. 1096/fj.13-241752

33. Rohani, N., Hao, L., Alexis, M. S., Joughin, B. A., Krismer, K., Moufarrej, M. N., et al. (2019). Acidification of tumor at stromal boundaries drives transcriptome alterations associated with aggressive phenotypes. Cancer Research, 79(8), 1952-1966. https://doi.org/10.1158/0008-5472.CAN-18-1604

34. Chiche, J., Brahimi-Horn, M. C., \& Pouyssegur, J. (2010). Tumour hypoxia induces a metabolic shift causing acidosis: A common feature in cancer. Journal of Cellular and Molecular Medicine, 14(4), 771-794. https://doi.org/10.1111/j.1582-4934. 2009.00994.x

35. Reshkin, S. J., Greco, M. R., \& Cardone, R. A. (2014). Role of $\mathrm{pHi}$, and proton transporters in oncogene-driven neoplastic transformation. Philosophical Transactions of the Royal Society of London. Series B, Biological sciences, 369(1638), 20130100. https://doi.org/10.1098/rstb.2013.0100

36. Parks, S. K., Chiche, J., \& Pouyssegur, J. (2011). pH control mechanisms of tumor survival and growth. Journal of Cellular Physiology, 226(2), 299-308. https://doi.org/10.1002/jcp. 22400

37. Fang, J. S., Gillies, R. D., \& Gatenby, R. A. (2008). Adaptation to hypoxia and acidosis in carcinogenesis and tumor progression. Seminars in Cancer Biology, 18(5), 330-337. https://doi.org/10. 1016/j.semcancer.2008.03.011

38. Gillies, R. J. (2021). Cancer heterogeneity and metastasis: Life at the edge. Clinical \& Experimental Metastasis. https://doi.org/ 10.1007/s10585-021-10101-2

39. Pastorek, J., Pastorekova, S., Callebaut, I., Mornon, J. P., Zelnik, V., Opavsky, R., et al. (1994). Cloning and characterization of $\mathrm{MN}$, a human tumor-associated protein with a domain homologous to carbonic anhydrase and a putative helix-loop-helix DNA binding segment. Oncogene, 9(10), 2877-2888.

40. Opavsky, R., Pastorekova, S., Zelnik, V., Gibadulinova, A., Stanbridge, E. J., Zavada, J., et al. (1996). Human MN/CA9 gene, a novel member of the carbonic anhydrase family: Structure and exon to protein domain relationships. Genomics, 33(3), 480-487. https://doi.org/10.1006/geno.1996.0223

41. Innocenti, A., Pastorekova, S., Pastorek, J., Scozzafava, A., De Simone, G., \& Supuran, C. T. (2009). The proteoglycan region of the tumor-associated carbonic anhydrase isoform IX acts as anintrinsic buffer optimizing $\mathrm{CO} 2$ hydration at acidic $\mathrm{pH}$ values characteristic of solid tumors. Bioorganic \& Medicinal Chemistry Letters, 19(20), 5825-5828. https://doi.org/10.1016/j.bmcl. 2009.08.088

42. Mahon, B. P., Bhatt, A., Socorro, L., Driscoll, J. M., Okoh, C., Lomelino, C. L., et al. (2016). The structure of carbonic anhydrase IX is adapted for low-pH catalysis. Biochemistry, 55(33), 4642-4653. https://doi.org/10.1021/acs.biochem.6b00243

43. Wykoff, C. C., Beasley, N. J., Watson, P. H., Turner, K. J., Pastorek, J., Sibtain, A., et al. (2000). Hypoxia-inducible expression of tumor-associated carbonic anhydrases. Cancer Research, 60(24), 7075-7083.

44. Ditte, P., Dequiedt, F., Svastova, E., Hulikova, A., OhradanovaRepic, A., Zatovicova, M., et al. (2011). Phosphorylation of carbonic anhydrase IX controls its ability to mediate extracellular acidification in hypoxic tumors. Cancer Research, 71(24), 7558-7567. https://doi.org/10.1158/0008-5472.CAN-11-2520

45. McDonald, P. C., Chafe, S. C., Brown, W. S., Saberi, S., Swayampakula, M., Venkateswaran, G., et al. (2019). Regulation of $\mathrm{pH}$ by carbonic anhydrase 9 mediates survival of pancreatic cancer cells with activated KRAS in response to hypoxia. Gastroenterology, 157(3), 823-837. https://doi.org/10.1053/j.gastro.2019. 05.004

46. Takacova, M., Holotnakova, T., Barathova, M., Pastorekova, S., Kopacek, J., \& Pastorek, J. (2010). Src induces expression of carbonic anhydrase IX via hypoxia-inducible factor 1. Oncology Reports, 23(3), 869-874.

47. Takacova, M., Bullova, P., Simko, V., Skvarkova, L., Poturnajova, M., Feketeova, L., et al. (2014). Expression pattern of carbonic anhydrase IX in Medullary thyroid carcinoma supports a role for RET-mediated activation of the HIF pathway. American Journal of Pathology, 184(4), 953-965. https://doi.org/10.1016/j.ajpath. 2014.01.002

48. Panisova, E., Kery, M., Sedlakova, O., Brisson, L., Debreova, M., Sboarina, M., et al. (2017). Lactate stimulates CA IX expression in normoxic cancer cells. Oncotarget, 8(44), 77819-77835. https://doi.org/10.18632/oncotarget.20836

49. Kappler, M., Pabst, U., Weinholdt, C., Taubert, H., Rot, S., Kaune, T., et al. (2019). Causes and consequences of a glutamine 
induced normoxic HIF1 Activity for the tumor metabolism. Int J Mol Sci, 20(19). https://doi.org/10.3390/ijms20194742.

50. Svastova, E., Hulikova, A., Rafajova, M., Zat'ovicova, M., Gibadulinova, A., Casini, A., et al. (2004). Hypoxia activates the capacity of tumor-associated carbonic anhydrase IX to acidify extracellular pH. FEBS Letters, 577(3), 439-445. https://doi.org/ 10.1016/j.febslet.2004.10.043

51. Swietach, P., Patiar, S., Supuran, C. T., Harris, A. L., \& VaughanJones, R. D. (2009). The role of carbonic anhydrase 9 in regulating extracellular and intracellular ph in three-dimensional tumor cell growths. Journal of Biological Chemistry, 284(30), 20299-20310. https://doi.org/10.1074/jbc.M109.006478

52. Lee, S. H., McIntyre, D., Honess, D., Hulikova, A., PachecoTorres, J., Cerdan, S., et al. (2018). Carbonic anhydrase IX is a $\mathrm{pH}$-stat that sets an acidic tumour extracellular $\mathrm{pH}$ in vivo. British Journal of Cancer, 119(5), 622-630. https://doi.org/10.1038/ s41416-018-0216-5

53. Morgan, P. E., Pastorekova, S., Stuart-Tilley, A. K., Alper, S. L., \& Casey, J. R. (2007). Interactions of transmembrane carbonic anhydrase, CAIX, with bicarbonate transporters. American Journal of Physiology. Cell Physiology, 293(2), C738-748. https:// doi.org/10.1152/ajpcell.00157.2007

54. Svastova, E., Witarski, W., Csaderova, L., Kosik, I., Skvarkova, L., Hulikova, A., et al. (2012). Carbonic anhydrase IX interacts with bicarbonate transporters in lamellipodia and increases cell migration via its catalytic domain. Journal of Biological Chemistry, 287(5), 3392-3402. https://doi.org/10.1074/jbc.M111. 286062

55. Orlowski, A., De Giusti, V. C., Morgan, P. E., Aiello, E. A., \& Alvarez, B. V. (2012). Binding of carbonic anhydrase IX to extracellular loop 4 of the NBCe1 Na+/HCO3- cotransporter enhances NBCe1-mediated HCO3- influx in the rat heart. American Journal of Physiology. Cell Physiology, 303(1), C69-80. https://doi.org/10.1152/ajpcell.00431.2011

56. Jamali, S., Klier, M., Ames, S., Barros, L. F., McKenna, R., Deitmer, J. W., et al. (2015). Hypoxia-induced carbonic anhydrase IX facilitates lactate flux in human breast cancer cells by noncatalytic function. Science and Reports, 5, 13605. https://doi.org/ 10.1038/srep13605

57. Ames, S., Pastorekova, S., \& Becker, H. M. (2018). The proteoglycan-like domain of carbonic anhydrase IX mediates non-catalytic facilitation of lactate transport in cancer cells. Oncotarget, 9(46), 27940-27957. https://doi.org/10.18632/oncotarget.25371

58. Ames, S., Andring, J. T., McKenna, R., \& Becker, H. M. (2019). CAIX forms a transport metabolon with monocarboxylate transporters in human breast cancer cells. Oncogene. https://doi.org/ 10.1038/s41388-019-1098-6

59. Liskova, V., Hudecova, S., Lencesova, L., Iuliano, F., Sirova, M., Ondrias, K., et al. (2019). Type 1 sodium calcium exchanger forms a complex with carbonic anhydrase IX and via reverse mode activity contributes to $\mathrm{pH}$ control in hypoxic tumors. Cancers (Basel), 11(8). https://doi.org/10.3390/cancers11081139.

60. Chafe, S. C., McDonald, P. C., Saberi, S., Nemirovsky, O., Venkateswaran, G., Burugu, S., et al. (2019). Targeting hypoxiainduced carbonic anhydrase IX enhances immune-checkpoint blockade locally and systemically. Cancer Immunology Research, 7(7), 1064-1078. https://doi.org/10.1158/2326-6066. CIR-18-0657

61. Chiche, J., Ilc, K., Laferriere, J., Trottier, E., Dayan, F., Mazure, N. M., et al. (2009). Hypoxia-inducible carbonic anhydrase IX and XII promote tumor cell growth by counteracting acidosis through the regulation of the intracellular $\mathrm{pH}$. Cancer Research, 69(1), 358-368. https://doi.org/10.1158/0008-5472. CAN-08-2470

62. McIntyre, A., Hulikova, A., Ledaki, I., Snell, C., Singleton, D., Steers, G., et al. (2016). Disrupting hypoxia-induced bicarbonate transport acidifies tumor cells and suppresses tumor growth. Cancer Research, 76(13), 3744-3755. https:// doi.org/10.1158/0008-5472.CAN-15-1862

63. Parks, S. K., Cormerais, Y., Durivault, J., \& Pouyssegur, J. (2017). Genetic disruption of the pHi-regulating proteins $\mathrm{Na}+/$ $\mathrm{H}+$ exchanger 1 (SLC9A1) and carbonic anhydrase 9 severely reduces growth of colon cancer cells. Oncotarget, 8(6), 1022510237. https://doi.org/10.18632/oncotarget.14379

64. Pacchiano, F., Carta, F., McDonald, P. C., Lou, Y., Vullo, D., Scozzafava, A., et al. (2011). Ureido-substituted benzenesulfonamides potently inhibit carbonic anhydrase IX and show antimetastatic activity in a model of breast cancer metastasis. Journal of Medicinal Chemistry, 54(6), 1896-1902. https://doi. org/10.1021/jm101541x

65. Lock, F. E., McDonald, P. C., Lou, Y., Serrano, I., Chafe, S. C., Ostlund, C., et al. (2013). Targeting carbonic anhydrase IX depletes breast cancer stem cells within the hypoxic niche. Oncogene, 32(44), 5210-5219. https://doi.org/10.1038/onc. 2012.550

66. Ledaki, I., McIntyre, A., Wigfield, S., Buffa, F., McGowan, S., Baban, D., et al. (2015). Carbonic anhydrase IX induction defines a heterogeneous cancer cell response to hypoxia and mediates stem cell-like properties and sensitivity to HDAC inhibition. Oncotarget, 6(23), 19413-19427. https://doi.org/ 10.18632/oncotarget.4989

67. Neri, D., \& Supuran, C. T. (2011). Interfering with pH regulation in tumours as a therapeutic strategy. Nature Reviews Drug Discovery, 10(10), 767-777. https://doi.org/10.1038/nrd3554

68. Pastorek, J., \& Pastorekova, S. (2015). Hypoxia-induced carbonic anhydrase IX as a target for cancer therapy: From biology to clinical use. Seminars in Cancer Biology, 31, 52-64. https://doi.org/10.1016/j.semcancer.2014.08.002

69. Strapcova, S., Takacova, M., Csaderova, L., Martinelli, P., Lukacikova, L., Gal, V., et al. (2020). Clinical and pre-clinical evidence of carbonic anhydrase IX in pancreatic cancer and its high expression in pre-cancerous lesions. Cancers (Basel), 12(8). https://doi.org/10.3390/cancers 12082005.

70. Kery, M., Oravcova, N., Radenkovic, S., Iuliano, F., Tomaskova, J., \& Golias, T. (2018). Pyruvate dehydrogenase kinase 1 and carbonic anhydrase IX targeting in hypoxic tumors. Neoplasma, 66(1), 63-72. https://doi.org/10.4149/neo_2018_ 180531 N357

71. Gibadulinova, A., Bullova, P., Strnad, H., Pohlodek, K., Jurkovicova, D., Takacova, M., et al. (2020). CAIX-mediated control of LIN28/let-7 axis contributes to metabolic adaptation of breast cancer cells to hypoxia. International Journal of Molecular Sciences, 21, 19. https://doi.org/10.3390/ijms21124299

72. Benej, M., Svastova, E., Banova, R., Kopacek, J., Gibadulinova, A., Kery, M., et al. (2020). CA IX stabilizes intracellular pH to maintain metabolic reprogramming and proliferation in hypoxia. Frontiers in Oncology, 10, 1462. https://doi.org/10.3389/fonc. 2020.01462

73. Becker, H. M. (2020). Carbonic anhydrase IX and acid transport in cancer. British Journal of Cancer, 122(2), 157-167. https:// doi.org/10.1038/s41416-019-0642-z

74. Harguindey, S., Arranz, J. L., Polo Orozco, J. D., Rauch, C., Fais, S., Cardone, R. A., et al. (2013). Cariporide and other new and powerful NHE1 inhibitors as potentially selective anticancer drugs-An integral molecular/biochemical/metabolic/clinical approach after one hundred years of cancer research. Journal of Translational Medicine, 11, 282. https://doi.org/10.1186/ 1479-5876-11-282

75. Lamonte, G., Tang, X., Chen, J. L., Wu, J., Ding, C. K., Keenan, M. M., et al. (2013). Acidosis induces reprogramming of cellular metabolism to mitigate oxidative stress. Cancer Metab, 1(1), 23. https://doi.org/10.1186/2049-3002-1-23 
76. Svastova, E., \& Pastorekova, S. (2013). Carbonic anhydrase IX: A hypoxia-controlled "catalyst" of cell migration. Cell Adhesion \& Migration, 7(2), 226-231. https://doi.org/10.4161/cam.23257

77. McDonald, P. C., Swayampakula, M., \& Dedhar, S. (2018). Coordinated regulation of metabolic transporters and migration/invasion by carbonic anhydrase IX. Metabolites, 8(1). https://doi.org/ 10.3390/metabo8010020.

78. Csaderova, L., Debreova, M., Radvak, P., Stano, M., Vrestiakova, M., Kopacek, J., et al. (2013). The effect of carbonic anhydrase IX on focal contacts during cell spreading and migration. Frontiers in Physiology, 4, 271. https://doi.org/10.3389/fphys.2013. 00271

79. Radvak, P., Repic, M., Svastova, E., Takacova, M., Csaderova, L., Strnad, H., et al. (2013). Suppression of carbonic anhydrase IX leads to aberrant focal adhesion and decreased invasion of tumor cells. Oncology Reports, 29(3), 1147-1153. https://doi. org/10.3892/or.2013.2226

80. Svastova, E., Zilka, N., Zat'ovicova, M., Gibadulinova, A., Ciampor, F., Pastorek, J., et al. (2003). Carbonic anhydrase IX reduces E-cadherin-mediated adhesion of MDCK cells via interaction with beta-catenin. Experimental Cell Research, 290(2), 332-345. https://doi.org/10.1016/s0014-4827(03)00351-3

81. Debreova, M., Csaderova, L., Burikova, M., Lukacikova, L., Kajanova, I., Sedlakova, O., et al. (2019). CAIX regulates invadopodia formation through both a $\mathrm{pH}$-dependent mechanism and interplay with actin regulatory proteins. Int J Mol Sci, 20(11). https://doi.org/10.3390/ijms20112745.

82. Swayampakula, M., McDonald, P. C., Vallejo, M., Coyaud, E., Chafe, S. C., Westerback, A., et al. (2017). The interactome of metabolic enzyme carbonic anhydrase IX reveals novel roles in tumor cell migration and invadopodia/MMP14-mediated invasion. Oncogene, 36(45), 6244-6261. https://doi.org/10.1038/onc. 2017.219

83. Venkateswaran, G., \& Dedhar, S. (2020). Interplay of carbonic anhydrase IX with amino acid and acid/base transporters in the hypoxic tumor microenvironment. Front Cell Dev Biol, 8, 602668. https://doi.org/10.3389/fcell.2020.602668

84. Stock, C., \& Schwab, A. (2009). Protons make tumor cells move like clockwork. Pflugers Archiv. European Journal of Physiology, 458(5), 981-992. https://doi.org/10.1007/s00424-009-0677-8

85. LeBleu, V. S., O'Connell, J. T., Gonzalez Herrera, K. N., Wikman, H., Pantel, K., Haigis, M. C., et al. (2014). PGC-1alpha mediates mitochondrial biogenesis and oxidative phosphorylation in cancer cells to promote metastasis. Nat Cell Biol, 16(10), 992-1003, 1001-1015. https://doi.org/10.1038/ncb3039.

86. Jiang, L., Xiao, L., Sugiura, H., Huang, X., Ali, A., Kuro-o, M., et al. (2015). Metabolic reprogramming during TGFbeta1induced epithelial-to-mesenchymal transition. Oncogene, 34(30), 3908-3916. https://doi.org/10.1038/onc.2014.321

87. Hui, E. P., Chan, A. T., Pezzella, F., Turley, H., To, K. F., Poon, T. C., et al. (2002). Coexpression of hypoxia-inducible factors 1alpha and 2alpha, carbonic anhydrase IX, and vascular endothelial growth factor in nasopharyngeal carcinoma and relationship to survival. Clinical Cancer Research, 8(8), 2595-2604.

88. Tomes, L., Emberley, E., Niu, Y., Troup, S., Pastorek, J., Strange, K., et al. (2003). Necrosis and hypoxia in invasive breast carcinoma. Breast Cancer Research and Treatment, 81(1), 61-69. https://doi.org/10.1023/A:1025476722493

89. Rademakers, S. E., Lok, J., van der Kogel, A. J., Bussink, J., \& Kaanders, J. H. (2011). Metabolic markers in relation to hypoxia; Staining patterns and colocalization of pimonidazole, HIF-1alpha, CAIX, LDH-5, GLUT-1, MCT1 and MCT4. BMC Cancer, 11, 167. https://doi.org/10.1186/1471-2407-11-167

90. Mayer, A., Schneider, F., Vaupel, P., Sommer, C., \& Schmidberger, H. (2012). Differential expression of HIF-1 in glioblastoma multiforme and anaplastic astrocytoma. International
Journal of Oncology, 41(4), 1260-1270. https://doi.org/10.3892/ ijo.2012.1555

91. Rohan, S. M., Xiao, Y., Liang, Y., Dudas, M. E., Al-Ahmadie, H. A., Fine, S. W., et al. (2011). Clear-cell papillary renal cell carcinoma: Molecular and immunohistochemical analysis with emphasis on the von Hippel-Lindau gene and hypoxia-inducible factor pathway-related proteins. Modern Pathology, 24(9), 12071220. https://doi.org/10.1038/modpathol.2011.80

92. Ord, J. J., Streeter, E. H., Roberts, I. S., Cranston, D., \& Harris, A. L. (2005). Comparison of hypoxia transcriptome in vitro with in vivo gene expression in human bladder cancer. British Journal of Cancer, 93(3), 346-354. https://doi.org/10.1038/sj.bjc.66026 66

93. Airley, R. E., Loncaster, J., Raleigh, J. A., Harris, A. L., Davidson, S. E., Hunter, R. D., et al. (2003). GLUT-1 and CAIX as intrinsic markers of hypoxia in carcinoma of the cervix: Relationship to pimonidazole binding. International Journal of Cancer, 104(1), 85-91. https://doi.org/10.1002/ijc.10904

94. Dooms, C., van Baardwijk, A., Verbeken, E., van Suylen, R. J., Stroobants, S., De Ruysscher, D., et al. (2009). Association between 18F-fluoro-2-deoxy-D-glucose uptake values and tumor vitality: Prognostic value of positron emission tomography in early-stage non-small cell lung cancer. Journal of Thoracic Oncology, 4(7), 822-828. https://doi.org/10.1097/JTO.0b013 e3181a97df7

95. Koukourakis, M. I., Pitiakoudis, M., Giatromanolaki, A., Tsarouha, A., Polychronidis, A., Sivridis, E., et al. (2006). Oxygen and glucose consumption in gastrointestinal adenocarcinomas: Correlation with markers of hypoxia, acidity and anaerobic glycolysis. Cancer Science, 97(10), 1056-1060. https://doi.org/10. 1111/j.1349-7006.2006.00298.x

96. Schmidt, D. R., Patel, R., Kirsch, D. G., Lewis, C. A., Vander Heiden, M. G., \& Locasale, J. W. (2021). Metabolomics in cancer research and emerging applications in clinical oncology. $C A$ : A Cancer Journal for Clinicians, 71(4), 333-358. https://doi.org/ 10.3322/caac. 21670

97. Muir, A., Danai, L. V., \& Vander Heiden, M. G. (2018). Microenvironmental regulation of cancer cell metabolism: implications for experimental design and translational studies. Dis Model Mech, 11(8). https://doi.org/10.1242/dmm.035758.

98. Bjorling, E., \& Uhlen, M. (2008). Antibodypedia, a portal for sharing antibody and antigen validation data. Molecular and Cellular Proteomics, 7(10), 2028-2037. https://doi.org/10.1074/ mcp.M800264-MCP200

99. Helsby, M. A., Leader, P. M., Fenn, J. R., Gulsen, T., Bryant, C., Doughton, G., et al. (2014). CiteAb: A searchable antibody database that ranks antibodies by the number of times they have been cited. BMC Cell Biology, 15, 6. https://doi.org/10.1186/ 1471-2121-15-6

100. van Kuijk, S. J., Yaromina, A., Houben, R., Niemans, R., Lambin, P., \& Dubois, L. J. (2016). Prognostic significance of carbonic anhydrase IX expression in cancer patients: A meta-analysis. Frontiers in Oncology, 6, 69. https://doi.org/10.3389/fonc.2016. 00069

101. Weller, M. G. (2018). Ten Basic Rules of Antibody Validation. Analytical Chemistry Insights, 13, 1177390118757462. https:// doi.org/10.1177/1177390118757462

102. Dungwa, J. V., Hunt, L. P., \& Ramani, P. (2012). Carbonic anhydrase IX up-regulation is associated with adverse clinicopathologic and biologic factors in neuroblastomas. Human Pathology, 43(10), 1651-1660. https://doi.org/10.1016/j.humpath.2011.12. 006

103. Korkolopoulou, P., Perdiki, M., Thymara, I., Boviatsis, E., Agrogiannis, G., Kotsiakis, X., et al. (2007). Expression of hypoxia-related tissue factors in astrocytic gliomas. A multivariate survival study with emphasis upon carbonic anhydrase IX. 
Hum Pathol, 38(4), 629-638. https://doi.org/10.1016/j.humpath. 2006.07.020

104. Ameis, H. M., Drenckhan, A., Freytag, M., Izbicki, J. R., Supuran, C. T., Reinshagen, K., et al. (2016). Carbonic anhydrase IX correlates with survival and is a potential therapeutic target for neuroblastoma. Journal of Enzyme Inhibition and Medicinal Chemistry, 31(3), 404-409. https://doi.org/10.3109/14756366. 2015.1029471

105. Jarvela, S., Parkkila, S., Bragge, H., Kahkonen, M., Parkkila, A. K., Soini, Y., et al. (2008). Carbonic anhydrase IX in oligodendroglial brain tumors. BMC Cancer, 8, 1. https://doi.org/10.1186/ 1471-2407-8-1

106. Nordfors, K., Haapasalo, J., Korja, M., Niemela, A., Laine, J., Parkkila, A. K., et al. (2010). The tumour-associated carbonic anhydrases CA II, CA IX and CA XII in a group of medulloblastomas and supratentorial primitive neuroectodermal tumours: An association of CA IX with poor prognosis. BMC Cancer, 10, 148. https://doi.org/10.1186/1471-2407-10-148

107. Haapasalo, J. A., Nordfors, K. M., Hilvo, M., Rantala, I. J., Soini, Y., Parkkila, A. K., et al. (2006). Expression of carbonic anhydrase IX in astrocytic tumors predicts poor prognosis. Clinical Cancer Research, 12(2), 473-477. https://doi.org/10.1158/10780432.CCR-05-0848

108. Erpolat, O. P., Gocun, P. U., Akmansu, M., Ozgun, G., \& Akyol, G. (2013). Hypoxia-related molecules HIF-1alpha, CA9, and osteopontin: Predictors of survival in patients with high-grade glioma. Strahlentherapie und Onkologie, 189(2), 147-154. https://doi.org/10.1007/s00066-012-0262-5

109. Proescholdt, M. A., Merrill, M. J., Stoerr, E. M., Lohmeier, A., Pohl, F., \& Brawanski, A. (2012). Function of carbonic anhydrase IX in glioblastoma multiforme. Neuro-Oncology, 14(11), 1357-1366. https://doi.org/10.1093/neuonc/nos216

110. Yoo, H., Sohn, S., Nam, B. H., Min, H. S., Jung, E., Shin, S. H., et al. (2010). The expressions of carbonic anhydrase 9 and vascular endothelial growth factor in astrocytic tumors predict a poor prognosis. International Journal of Molecular Medicine, 26(1), 3-9. https://doi.org/10.3892/ijmm_00000427

111. Abraham, S., Hu, N., \& Jensen, R. (2012). Hypoxia-inducible factor-1-regulated protein expression and oligodendroglioma patient outcome: Comparison with established biomarkers and preoperative UCSF low-grade scoring system. Journal of Neuro-oncology, 108(3), 459-468. https://doi.org/10.1007/ s11060-012-0839-y

112. Jensen, R., \& Lee, J. (2012). Predicting outcomes of patients with intracranial meningiomas using molecular markers of hypoxia, vascularity, and proliferation. Neurosurgery, 71(1), 146-156. https://doi.org/10.1227/NEU.0b013e3182567886

113. Sooman, L., Freyhult, E., Jaiswal, A., Navani, S., Edqvist, P. H., Ponten, F., et al. (2015). FGF2 as a potential prognostic biomarker for proneural glioma patients. Acta Oncologica, 54(3), 385-394. https://doi.org/10.3109/0284186X.2014.951492

114. Flynn, J. R., Wang, L., Gillespie, D. L., Stoddard, G. J., Reid, J. K., Owens, J., et al. (2008). Hypoxia-regulated protein expression, patient characteristics, and preoperative imaging as predictors of survival in adults with glioblastoma multiforme. Cancer, 113(5), 1032-1042. https://doi.org/10.1002/cncr.23678

115. Preusser, M., Wolfsberger, S., Haberler, C., Breitschopf, H., Czech, T., Slavc, I., et al. (2005). Vascularization and expression of hypoxia-related tissue factors in intracranial ependymoma and their impact on patient survival. Acta Neuropathologica, 109(2), 211-216. https://doi.org/10.1007/s00401-004-0938-8

116. Couvelard, A., O’Toole, D., Turley, H., Leek, R., Sauvanet, A., Degott, C., et al. (2005). Microvascular density and hypoxiainducible factor pathway in pancreatic endocrine tumours: Negative correlation of microvascular density and VEGF expression with tumour progression. British Journal of Cancer, 92(1), 94-101. https://doi.org/10.1038/sj.bjc.6602245

117. Couvelard, A., O’Toole, D., Leek, R., Turley, H., Sauvanet, A., Degott, C., et al. (2005). Expression of hypoxia-inducible factors is correlated with the presence of a fibrotic focus and angiogenesis in pancreatic ductal adenocarcinomas. Histopathology, 46(6), 668-676. https://doi.org/10.1111/j.1365-2559.2005.02160.x

118. Chang, D. T., Chapman, C. H., Norton, J. A., Visser, B., Fisher, G. A., Kunz, P., et al. (2010). Expression of p16(INK4A) but not hypoxia markers or poly adenosine diphosphate-ribose polymerase is associated with improved survival in patients with pancreatic adenocarcinoma. Cancer, 116(22), 5179-5187. https://doi. org/10.1002/cncr.25481

119. Hiraoka, N., Ino, Y., Sekine, S., Tsuda, H., Shimada, K., Kosuge, T., et al. (2010). Tumour necrosis is a postoperative prognostic marker for pancreatic cancer patients with a high interobserver reproducibility in histological evaluation. British Journal of Cancer, 103(7), 1057-1065. https://doi.org/10.1038/sj.bjc.6605854

120. Li, Y., Dong, M., Sheng, W., \& Huang, L. (2016). Roles of carbonic anhydrase IX in development of pancreatic cancer. Pathology Oncology Research, 22(2), 277-286. https://doi.org/10.1007/ s12253-015-9935-6

121. Schmitt, A. M., Schmid, S., Rudolph, T., Anlauf, M., Prinz, C., Kloppel, G., et al. (2009). VHL inactivation is an important pathway for the development of malignant sporadic pancreatic endocrine tumors. Endocrine-Related Cancer, 16(4), 1219-1227. https://doi.org/10.1677/ERC-08-0297

122. Yu, M., Zhou, Q., Zhou, Y., Fu, Z., Tan, L., Ye, X., et al. (2015). Metabolic phenotypes in pancreatic cancer. PLOS ONE, 10(2), e0115153. https://doi.org/10.1371/journal.pone.0115153

123. Trastour, C., Benizri, E., Ettore, F., Ramaioli, A., Chamorey, E., Pouyssegur, J., et al. (2007). HIF-1alpha and CA IX staining in invasive breast carcinomas: Prognosis and treatment outcome. International Journal of Cancer, 120(7), 1451-1458. https://doi. org/10.1002/ijc. 22436

124. Hussain, S. A., Ganesan, R., Reynolds, G., Gross, L., Stevens, A., Pastorek, J., et al. (2007). Hypoxia-regulated carbonic anhydrase IX expression is associated with poor survival in patients with invasive breast cancer. British Journal of Cancer, 96(1), 104-109. https://doi.org/10.1038/sj.bjc.6603530

125. Betof, A. S., Rabbani, Z. N., Hardee, M. E., Kim, S. J., Broadwater, G., Bentley, R. C., et al. (2012). Carbonic anhydrase IX is a predictive marker of doxorubicin resistance in early-stage breast cancer independent of HER2 and TOP2A amplification. British Journal of Cancer, 106(5), 916-922. https://doi.org/10.1038/bjc. 2012.32

126. Aomatsu, N., Yashiro, M., Kashiwagi, S., Kawajiri, H., Takashima, T., Ohsawa, M., et al. (2014). Carbonic anhydrase 9 is associated with chemosensitivity and prognosis in breast cancer patients treated with taxane and anthracycline. BMC Cancer, 14, 400. https://doi.org/10.1186/1471-2407-14-400

127. Lou, Y., McDonald, P. C., Oloumi, A., Chia, S., Ostlund, C., Ahmadi, A., et al. (2011). Targeting tumor hypoxia: Suppression of breast tumor growth and metastasis by novel carbonic anhydrase IX inhibitors. Cancer Research, 71(9), 3364-3376. https://doi.org/10.1158/0008-5472.CAN-10-4261

128. Tan, E. Y., Yan, M., Campo, L., Han, C., Takano, E., Turley, H., et al. (2009). The key hypoxia regulated gene CAIX is upregulated in basal-like breast tumours and is associated with resistance to chemotherapy. British Journal of Cancer, 100(2), 405-411. https://doi.org/10.1038/sj.bjc.6604844

129. Brennan, D. J., Jirstrom, K., Kronblad, A., Millikan, R. C., Landberg, G., Duffy, M. J., et al. (2006). CA IX is an independent prognostic marker in premenopausal breast cancer patients with one to three positive lymph nodes and a putative marker of 
radiation resistance. Clinical Cancer Research, 12(21), 64216431. https://doi.org/10.1158/1078-0432.CCR-06-0480

130. Generali, D., Fox, S. B., Berruti, A., Brizzi, M. P., Campo, L., Bonardi, S., et al. (2006). Role of carbonic anhydrase IX expression in prediction of the efficacy and outcome of primary epirubicin/tamoxifen therapy for breast cancer. Endocrine-Related Cancer, 13(3), 921-930. https://doi.org/10.1677/ erc. 1.01216

131. Kyndi, M., Sorensen, F. B., Knudsen, H., Alsner, J., Overgaard, M., Nielsen, H. M., et al. (2008). Carbonic anhydrase IX and response to postmastectomy radiotherapy in high-risk breast cancer: A subgroup analysis of the DBCG82 b and c trials. Breast Cancer Research, 10(2), R24. https://doi.org/10.1186/bcr1981

132. Neumeister, V. M., Sullivan, C. A., Lindner, R., Lezon-Geyda, K., Li, J., Zavada, J., et al. (2012). Hypoxia-induced protein CAIX is associated with somatic loss of BRCA1 protein and pathway activity in triple negative breast cancer. Breast Cancer Research and Treatment, 136(1), 67-75. https://doi.org/10.1007/ s10549-012-2232-0

133. Doyen, J., Trastour, C., Ettore, F., Peyrottes, I., Toussant, N., Gal, J., et al. (2014). Expression of the hypoxia-inducible monocarboxylate transporter MCT4 is increased in triple negative breast cancer and correlates independently with clinical outcome. Biochemical and Biophysical Research Communications, 451(1), 54-61. https://doi.org/10.1016/j.bbrc.2014.07.050

134. Pinheiro, C., Sousa, B., Albergaria, A., Paredes, J., Dufloth, R., Vieira, D., et al. (2011). GLUT1 and CAIX expression profiles in breast cancer correlate with adverse prognostic factors and MCT1 overexpression. Histology and Histopathology, 26(10), 1279-1286. https://doi.org/10.14670/HH-26.1279

135. Garcia, S., Dales, J. P., Charafe-Jauffret, E., Carpentier-Meunier, S., Andrac-Meyer, L., Jacquemier, J., et al. (2007). Poor prognosis in breast carcinomas correlates with increased expression of targetable CD146 and c-Met and with proteomic basal-like phenotype. Human Pathology, 38(6), 830-841. https://doi.org/ 10.1016/j.humpath.2006.11.015

136. Bane, A. L., Whelan, T. J., Pond, G. R., Parpia, S., Gohla, G., Fyles, A. W., et al. (2014). Tumor factors predictive of response to hypofractionated radiotherapy in a randomized trial following breast conserving therapy. Annals of Oncology, 25(5), 992-998. https://doi.org/10.1093/annonc/mdu090

137. Kim, H. M., Jung, W. H., \& Koo, J. S. (2014). Site-specific metabolic phenotypes in metastatic breast cancer. Journal of Translational Medicine, 12, 354. https://doi.org/10.1186/ s12967-014-0354-3

138. Lancashire, L. J., Powe, D. G., Reis-Filho, J. S., Rakha, E., Lemetre, C., Weigelt, B., et al. (2010). A validated gene expression profile for detecting clinical outcome in breast cancer using artificial neural networks. Breast Cancer Research and Treatment, 120(1), 83-93. https://doi.org/10.1007/s10549-009-0378-1

139. Kornegoor, R., Verschuur-Maes, A. H., Buerger, H., Hogenes, M. C., de Bruin, P. C., Oudejans, J. J., et al. (2012). Fibrotic focus and hypoxia in male breast cancer. Modern Pathology, 25(10), 1397-1404. https://doi.org/10.1038/modpathol.2012.101

140. Noh, S., Kim, J. Y., \& Koo, J. S. (2014). Metabolic differences in estrogen receptor-negative breast cancer based on androgen receptor status. Tumour Biology, 35(8), 8179-8192. https://doi. org/10.1007/s13277-014-2103-X

141. Currie, M. J., Beardsley, B. E., Harris, G. C., Gunningham, S. P., Dachs, G. U., Dijkstra, B., et al. (2013). Immunohistochemical analysis of cancer stem cell markers in invasive breast carcinoma and associated ductal carcinoma in situ: Relationships with markers of tumor hypoxia and microvascularity. Human Pathology, 44(3), 402-411. https://doi.org/10.1016/j.humpath. 2012.06.004
142. Deb, S., Johansson, I., Byrne, D., Nilsson, C., kConFab, I., Constable, L., et al. (2014). Nuclear HIF1A expression is strongly prognostic in sporadic but not familial male breast cancer. Mod Pathol, 27(9), 1223-1230. https://doi.org/10.1038/modpathol. 2013.231

143. Beketic-Oreskovic, L., Ozretic, P., Rabbani, Z. N., Jackson, I. L., Sarcevic, B., Levanat, S., et al. (2011). Prognostic significance of carbonic anhydrase IX (CA-IX), endoglin (CD105) and 8-hydroxy-2'-deoxyguanosine (8-OHdG) in breast cancer patients. Pathology Oncology Research, 17(3), 593-603. https:// doi.org/10.1007/s12253-010-9355-6

144. Kaya, A. O., Gunel, N., Benekli, M., Akyurek, N., Buyukberber, S., Tatli, H., et al. (2012). Hypoxia inducible factor-1 alpha and carbonic anhydrase IX overexpression are associated with poor survival in breast cancer patients. Journal of B.U.ON., 17(4), 663-668.

145. Silva, P., Slevin, N. J., Sloan, P., Valentine, H., Ryder, D., Price, P., et al. (2010). Use of multiple biological markers in radiotherapy-treated head and neck cancer. Journal of Laryngology and Otology, 124(6), 650-658. https://doi.org/10.1017/S002221511 0000228

146. Koukourakis, M. I., Giatromanolaki, A., Sivridis, E., Simopoulos, K., Pastorek, J., Wykoff, C. C., et al. (2001). Hypoxia-regulated carbonic anhydrase-9 (CA9) relates to poor vascularization and resistance of squamous cell head and neck cancer to chemoradiotherapy. Clinical Cancer Research, 7(11), 3399-3403.

147. Koukourakis, M. I., Bentzen, S. M., Giatromanolaki, A., Wilson, G. D., Daley, F. M., Saunders, M. I., et al. (2006). Endogenous markers of two separate hypoxia response pathways (hypoxia inducible factor 2 alpha and carbonic anhydrase 9) are associated with radiotherapy failure in head and neck cancer patients recruited in the CHART randomized trial. Journal of Clinical Oncology, 24(5), 727-735. https://doi.org/10.1200/JCO.2005.02. 7474

148. Bernstein, J. M., Andrews, T. D., Slevin, N. J., West, C. M., \& Homer, J. J. (2015). Prognostic value of hypoxia-associated markers in advanced larynx and hypopharynx squamous cell carcinoma. The Laryngoscope, 125(1), E8-15. https://doi.org/ 10.1002/lary.24933

149. Choi, S. W., Kim, J. Y., Park, J. Y., Cha, I. H., Kim, J., \& Lee, S. (2008). Expression of carbonic anhydrase IX is associated with postoperative recurrence and poor prognosis in surgically treated oral squamous cell carcinoma. Human Pathology, 39(9), 1317-1322. https://doi.org/10.1016/j.humpath.2007.10.026

150. De Schutter, H., Landuyt, W., Verbeken, E., Goethals, L., Hermans, R., \& Nuyts, S. (2005). The prognostic value of the hypoxia markers CA IX and GLUT 1 and the cytokines VEGF and IL 6 in head and neck squamous cell carcinoma treated by radiotherapy +/- chemotherapy. BMC Cancer, 5, 42. https://doi. org/10.1186/1471-2407-5-42

151. Douglas, C. M., Bernstein, J. M., Ormston, V. E., Hall, R. C., Merve, A., Swindell, R., et al. (2013). Lack of prognostic effect of carbonic anhydrase-9, hypoxia inducible factor-1alpha and bcl-2 in 286 patients with early squamous cell carcinoma of the glottic larynx treated with radiotherapy. Clinical Oncology (Royal College of Radiologists), 25(1), 59-65. https://doi.org/10. 1016/j.clon.2012.07.004

152. Heo, K., Kim, Y. H., Sung, H. J., Li, H. Y., Yoo, C. W., Kim, J. Y., et al. (2012). Hypoxia-induced up-regulation of apelin is associated with a poor prognosis in oral squamous cell carcinoma patients. Oral Oncology, 48(6), 500-506. https://doi.org/ 10.1016/j.oraloncology.2011.12.015

153. Kim, S. J., Shin, H. J., Jung, K. Y., Baek, S. K., Shin, B. K., Choi, J., et al. (2007). Prognostic value of carbonic anhydrase IX and $\mathrm{Ki}-67$ expression in squamous cell carcinoma of the tongue. 
Japanese Journal of Clinical Oncology, 37(11), 812-819. https:// doi.org/10.1093/jjco/hym121

154. Perez-Sayans, M., Suarez-Penaranda, J. M., Pilar, G. D., Supuran, C. T., Pastorekova, S., Barros-Angueira, F., et al. (2012). Expression of CA-IX is associated with advanced stage tumors and poor survival in oral squamous cell carcinoma patients. Journal of Oral Pathology and Medicine, 41(9), 667-674. https://doi.org/10.1111/j.1600-0714. 2012.01147.x

155. Wachters, J. E., Schrijvers, M. L., Slagter-Menkema, L., Mastik, M., de Bock, G. H., Langendijk, J. A., et al. (2013). Prognostic significance of HIF-1a, CA-IX, and OPN in T1-T2 laryngeal carcinoma treated with radiotherapy. The Laryngoscope, 123(9), 2154-2160. https://doi.org/10.1002/lary.23831

156. Eriksen, J. G., Overgaard, J., Danish, H., Neck Cancer Study, G. (2007). Lack of prognostic and predictive value of CA IX in radiotherapy of squamous cell carcinoma of the head and neck with known modifiable hypoxia: An evaluation of the DAHANCA 5 study. Radiother Oncol, 83(3), 383-388. https:// doi.org/10.1016/j.radonc.2007.05.009

157. Le, Q. T., Shi, G., Cao, H., Nelson, D. W., Wang, Y., Chen, E. Y., et al. (2005). Galectin-1: A link between tumor hypoxia and tumor immune privilege. Journal of Clinical Oncology, 23(35), 8932-8941. https://doi.org/10.1200/JCO. 2005.02.0206

158. Nordsmark, M., Eriksen, J. G., Gebski, V., Alsner, J., Horsman, M. R., \& Overgaard, J. (2007). Differential risk assessments from five hypoxia specific assays: The basis for biologically adapted individualized radiotherapy in advanced head and neck cancer patients. Radiotherapy and Oncology, 83(3), 389-397. https://doi.org/10.1016/j.radonc.2007.04.021

159. Winter, S. C., Shah, K. A., Han, C., Campo, L., Turley, H., Leek, R., et al. (2006). The relation between hypoxiainducible factor (HIF)-1alpha and HIF-2alpha expression with anemia and outcome in surgically treated head and neck cancer. Cancer, 107(4), 757-766. https://doi.org/10. $1002 /$ cncr. 21983

160. Koukourakis, M. I., Giatromanolaki, A., Danielidis, V., \& Sivridis, E. (2008). Hypoxia inducible factor (HIf1alpha and HIF2alpha) and carbonic anhydrase 9 (CA9) expression and response of head-neck cancer to hypofractionated and accelerated radiotherapy. International Journal of Radiation Biology, 84(1), 47-52. https://doi.org/10.1080/09553000701616114

161. Kondo, Y., Yoshikawa, K., Omura, Y., Shinohara, A., Kazaoka, Y., Sano, J., et al. (2011). Clinicopathological significance of carbonic anhydrase 9, glucose transporter-1, Ki-67 and p53 expression in oral squamous cell carcinoma. Oncology Reports, 25(5), 1227-1233. https://doi.org/10.3892/or.2011. 1216

162. Brockton, N., Dort, J., Lau, H., Hao, D., Brar, S., Klimowicz, A., et al. (2011). High stromal carbonic anhydrase IX expression is associated with decreased survival in P16-negative head-and-neck tumors. International Journal of Radiation Oncology Biology Physics, 80(1), 249-257. https://doi.org/ 10.1016/j.ijrobp.2010.11.059

163. Brockton, N. T., Klimowicz, A. C., Bose, P., Petrillo, S. K., Konno, M., Rudmik, L., et al. (2012). High stromal carbonic anhydrase IX expression is associated with nodal metastasis and decreased survival in patients with surgically-treated oral cavity squamous cell carcinoma. Oral Oncology, 48(7), 615622. https://doi.org/10.1016/j.oraloncology.2012.01.018

164. Zheng, G., Peng, C., Jia, X., Gu, Y., Zhang, Z., Deng, Y., et al. (2015). ZEB1 transcriptionally regulated carbonic anhydrase 9 mediates the chemoresistance of tongue cancer via maintaining intracellular pH. Molecular Cancer, 14, 84. https://doi.org/10. 1186/s12943-015-0357-6
165. Sakata, K., Someya, M., Nagakura, H., Nakata, K., Oouchi, A., Takagi, M., et al. (2008). Brachytherapy for oral tongue cancer: An analysis of treatment results with various biological markers. Japanese Journal of Clinical Oncology, 38(6), 402-407. https://doi.org/10.1093/jjco/hyn050

166. Chen, Y., Li, X., Wu, S., Xu, G., Zhou, Y., Gong, L., et al. (2014). Expression of HIF-1alpha and CAIX in nasopharyngeal carcinoma and their correlation with patients' prognosis. Medical Oncology, 31(12), 304. https://doi.org/10.1007/ s12032-014-0304-1

167. Hwa, J. S., Kwon, O. J., Park, J. J., Woo, S. H., Kim, J. P., Ko, G. H., et al. (2015). The prognostic value of immunohistochemical markers for oral tongue squamous cell carcinoma. European Archives of Oto-Rhino-Laryngology, 272(10), 2953-2959. https://doi.org/10.1007/s00405-014-3254-5

168. Kwon, O. J., Park, J. J., Ko, G. H., Seo, J. H., Jeong, B. K., Kang, K. M., et al. (2015). HIF-1alpha and CA-IX as predictors of locoregional control for determining the optimal treatment modality for early-stage laryngeal carcinoma. Head and Neck, 37(4), 505-510. https://doi.org/10.1002/ hed. 23620

169. Han, M. W., Lee, H. J., Cho, K. J., Kim, J. S., Roh, J. L., Choi, S. H., et al. (2012). Role of FDG-PET as a biological marker for predicting the hypoxic status of tongue cancer. Head and Neck, 34(10), 1395-1402. https://doi.org/10.1002/hed.21945

170. Roh, J. L., Cho, K. J., Kwon, G. Y., Choi, S. H., Nam, S. Y., \& Kim, S. Y. (2008). Prognostic values of pathologic findings and hypoxia markers in 21 patients with salivary duct carcinoma. Journal of Surgical Oncology, 97(7), 596-600. https://doi.org/ $10.1002 /$ jso. 21045

171. Roh, J. L., Cho, K. J., Kwon, G. Y., Ryu, C. H., Chang, H. W., Choi, S. H., et al. (2009). The prognostic value of hypoxia markers in T2-staged oral tongue cancer. Oral Oncology, 45(1), 63-68. https://doi.org/10.1016/j.oraloncology.2008.03. 017

172. Yang, J. S., Lin, C. W., Chuang, C. Y., Su, S. C., Lin, S. H., \& Yang, S. F. (2015). Carbonic anhydrase IX overexpression regulates the migration and progression in oral squamous cell carcinoma. Tumour Biology, 36(12), 9517-9524. https://doi. org/10.1007/s13277-015-3692-8

173. Eckert, A. W., Lautner, M. H., Schutze, A., Bolte, K., Bache, M., Kappler, M., et al. (2010). Co-expression of Hif1alpha and CAIX is associated with poor prognosis in oral squamous cell carcinoma patients. Journal of Oral Pathology and Medicine, 39(4), 313-317. https://doi.org/10.1111/j.1600-0714.2009. 00829.x

174. Jonathan, R. A., Wijffels, K. I., Peeters, W., de Wilde, P. C., Marres, H. A., Merkx, M. A., et al. (2006). The prognostic value of endogenous hypoxia-related markers for head and neck squamous cell carcinomas treated with ARCON. Radiotherapy and Oncology, 79(3), 288-297. https://doi.org/10. 1016/j.radonc.2006.04.008

175. Rademakers, S. E., Hoogsteen, I. J., Rijken, P. F., Oosterwijk, E., Terhaard, C. H., Doornaert, P. A., et al. (2013). Pattern of CAIX expression is prognostic for outcome and predicts response to ARCON in patients with laryngeal cancer treated in a phase III randomized trial. Radiotherapy and Oncology, 108(3), 517-522. https://doi.org/10.1016/j. radonc.2013.04.022

176. Gilchrist, K. W., Gray, R., Fowble, B., Tormey, D. C., Taylor, S. G., \& t. (1993). Tumor necrosis is a prognostic predictor for early recurrence and death in lymph node-positive breast cancer: A 10-year follow-up study of 728 Eastern Cooperative Oncology Group patients. Journal of Clinical Oncology, 11(10), 1929-1935. https://doi.org/10.1200/JCO.1993.11.10. 1929 
177. Ord, J. J., Agrawal, S., Thamboo, T. P., Roberts, I., Campo, L., Turley, H., et al. (2007). An investigation into the prognostic significance of necrosis and hypoxia in high grade and invasive bladder cancer. Journal of Urology, 178(2), 677-682. https:// doi.org/10.1016/j.juro.2007.03.112

178. Ramos-Vara, J. A., \& Miller, M. A. (2014). When tissue antigens and antibodies get along: Revisiting the technical aspects of immunohistochemistry-The red, brown, and blue technique. Veterinary Pathology, 51(1), 42-87. https://doi.org/10.1177/ 0300985813505879

179. Hartling, L., Milne, A., Hamm, M. P., Vandermeer, B., Ansari, M., Tsertsvadze, A., et al. (2013). Testing the
Newcastle Ottawa Scale showed low reliability between individual reviewers. Journal of Clinical Epidemiology, 66(9), 982-993. https://doi.org/10.1016/j.jclinepi.2013.03.003

Publisher's Note Springer Nature remains neutral with regard to jurisdictional claims in published maps and institutional affiliations. 